\title{
Article \\ A Meta-Analysis of the Protein Components in Rattlesnake Venom
}

\author{
Anant Deshwal ${ }^{1,+}+\mathbb{C}$, Phuc Phan ${ }^{2,+}$, Jyotishka Datta ${ }^{3}$, Ragupathy Kannan ${ }^{4}$ and Suresh Kumar Thallapuranam ${ }^{2, *}$ \\ 1 Division of Biology, University of Tennessee, Knoxville, TN 37996, USA; adeshwal@utk.edu \\ 2 Department of Chemistry and Biochemistry, University of Arkansas, Fayetteville, AR 72701, USA; \\ phucphan@uark.edu \\ 3 Department of Statistics, Virginia Polytechnic Institute and State University, Blacksburg, VA 24061, USA; \\ jyotishka@vt.edu \\ 4 Department of Biology, University of Arkansas-Fort Smith, Fort Smith, AR 72913, USA; \\ Ragupathy.Kannan@uafs.edu \\ * Correspondence: sthalla@uark.edu \\ + These authors contributed equally to this work.
}

check for updates

Citation: Deshwal, A.; Phan, P.; Datta, J.; Kannan, R.; Thallapuranam, S.K. A Meta-Analysis of the Protein Components in Rattlesnake Venom. Toxins 2021, 13, 372. https://doi.org/ $10.3390 /$ toxins 13060372

Received: 2 April 2021

Accepted: 21 May 2021

Published: 23 May 2021

Publisher's Note: MDPI stays neutral with regard to jurisdictional claims in published maps and institutional affiliations.

Copyright: (c) 2021 by the authors. Licensee MDPI, Basel, Switzerland. This article is an open access article distributed under the terms and conditions of the Creative Commons Attribution (CC BY) license (https:// creativecommons.org/licenses/by/ $4.0 /)$.

\begin{abstract}
The specificity and potency of venom components give them a unique advantage in developing various pharmaceutical drugs. Though venom is a cocktail of proteins, rarely are the synergy and association between various venom components studied. Understanding the relationship between various components of venom is critical in medical research. Using metaanalysis, we observed underlying patterns and associations in the appearance of the toxin families. For Crotalus, Dis has the most associations with the following toxins: PDE; BPP; CRL; CRiSP; LAAO; SVMP P-I and LAAO; SVMP P-III and LAAO. In Sistrurus venom, CTL and NGF have the most associations. These associations can predict the presence of proteins in novel venom and understand synergies between venom components for enhanced bioactivity. Using this approach, the need to revisit the classification of proteins as major components or minor components is highlighted. The revised classification of venom components is based on ubiquity, bioactivity, the number of associations, and synergies. The revised classification can be expected to trigger increased research on venom components, such as NGF, which have high biomedical significance. Using hierarchical clustering, we observed that the genera's venom compositions were similar, based on functional characteristics rather than phylogenetic relationships.
\end{abstract}

Keywords: rattlesnake; Crotalus; Sistrurus; venom; toxin; association

Key Contribution: Crotalus and Sistrurus, to determine the associations between toxin families. These results are expected to lead to a better understanding of the synergistic activities between these components. A synergistic relationship between toxins can be potentially exploited in the design and development of new pharmaceutical drugs.

\section{Introduction}

Venom study has become an integral part of the biomedical research [1] as various venom components have been critical in the development of new pharmaceutical drugs [2] that are potentially useful for the treatment of diabetes, strokes, heart attacks [3,4], and cancer [5-12]. For most extant research, venom is sourced from various venomous organisms, such as snakes, scorpions, spiders, etc. Among snakes, venomous snakes are distributed mainly in three families: Atractaspidae, Elapidae, Viperidae [13]. Venom from these snake families is highly complex and variable in composition [14-16]. The variation in biochemical composition of snake venom can occur between closely related species and within a single species itself [1,17-22]. For example, intragenus or intraspecific variation in venom in pit vipers and adders $[17,23]$ has been correlated to diet $[17,18,24,25]$ or topographical 
features $[26,27]$. One of the primary reasons for high diversity and plasticity in snake venom is frequent duplication of toxin-encoding genes and recruitment strategies [28-32] followed by functional and structural diversification [1,33-37].

Within the North and South American continent, it is suggested that the venom of Crotalidae has the highest variation in toxicity is associated with high proteolytic activity [38]. Rattlesnakes are a part of the Crotalinae subfamily and consist of two genera Crotalus and Sistrurus. They are native to the Americas ranging from southern Alberta, Saskatchewan, and southern British Columbia in Canada to central Argentina. There are approximately 32 species of rattlesnakes within the Crotalus and Sistrurus genus [39]. These snakes are found in many habitat types ranging from the Sonoran Desert of northwestern Mexico to alpine and cloud forest in central and southern Mexico [39]. They occur from below sea level in desert basins in California to about $4500 \mathrm{~m}$ in the Transverse Volcanic Cordillera of central Mexico [39]. Mexican Plateau and its fringing mountains have the highest diversity of rattlesnakes [39]. This high variability in the habitat type, altitude, and associated diet types, along with a large geographical range, allows the rattlesnakes to have high variability in their venom composition.

Rattlesnakes possess various different toxins from 10-20 protein families [7,30,40-42]. These families possess several enzymes, such as: L-amino acid oxidases (LAAO) [30,43-46], phosphodiesterase (PDE) [47-49], snake venom metalloproteases (SVMP) [50-52], serine proteases (SVSP) [44,53-55], phospholipases $\left(\mathrm{PLA}_{2}\right)$ [56-59].Additionally, rattlesnake venoms also contain nonenzymatic proteins like myotoxin a and its homologs [60-63], bradykininpotentiating peptides and bradykinin-inhibitory peptide (BPPs and BIPs) $[30,44,64,65]$, disintegrins (Dis) $[3,44,45,55,66-68]$, cysteine-rich secretory proteins (CRiSPs) $[2,45,55,62]$, and C-type lectins (CTL) [30,41,48,69]. It is not uncommon to have variation in venom composition within species $[17,23]$. This plasticity and variability of venom gives it a unique advantage in biomedical research.

Even though venom enjoys a unique advantage in biomedical research, it is plagued by three main issues: (i) absence of data on venom composition of several species within Crotalus genus (rare and/or topographically inaccessible species); (ii) high-cost associated with venom-based studies; (iii) high variability in venom composition rendering venom composition studies for all age classes in all populations of rattlesnakes impractical; and (iv) sparse data on the relationship between various venom components. These factors manifesting together often make it difficult to predict the venom components in any species. A natural solution to this issue is quantifying the relationship between venom components rather than individual units. For example, within Crotalus polystictus, the type and potency of proteins expressed vary with age and sex [48,69-71]. Many venom components discovered, such as LAAO and PDE, have not been explored for their potential biomedical applications [32,72]. However, based on the associations and ubiquity alone, it is evident that they do play a role during envenomation.

These new-found relationships between various protein components in snake venom may play key roles in developing suitable treatments for prevalent diseases. Such relationships between toxins, often termed synergisms, are joint effects of multiple toxins, which assert greater effects than the sum of individual potencies, thus allowing the individual components to be highly effective with only trace amounts [73,74]. In the current study, we conduct a meta-analysis to understand the relationship between various protein components in Crotalus and Sistrurus' venoms. We also report the frequency with which various proteins occur in Crotalus and Sistrurus' venoms. Here we re-classify venom components as major or minor based on their medical relevance, synergies with other toxins, frequency of occurrences.

\section{Result}

Our search consisting of six keywords and 14 databases produced 192 studies on Crotalus and Sistrurus venom. Out of these 192 studies, 77 studies are not included in the current meta-analysis; 36 out of 77 studies did not meet inclusion criteria, and 41 studies 
met the exclusion criteria. The remaining 115 full-text articles are included in the analysis. From these 115 articles, only 47 reported a relative abundance of venom components for Crotalus and Sistrurus species.

\subsection{Venom Constituents in Crotalus Venom}

We identified compositional venom studies, through both transcriptomic and proteomic technologies, for 30 entries, including species and subspecies, within the genus Crotalus. 46 protein families are present in Crotalus (Table 1). These protein families could be classified based on ubiquity or relationship with other proteins. There is little information regarding the venom composition of nine Crotalus species and subspecies (Table 1). 41 studies reported the relative abundance of protein constituents.

Table 1. Venom components within the Crotalus genus.

\begin{tabular}{|c|c|c|}
\hline Species & Venom Components & Reference \\
\hline C. adamanteus & $\begin{array}{l}\text { 5'NT, BPP, carboxypeptidase (E-Like), CNP, CRiSP, CTL, dipeptidase, Dis, EF-hand } \\
\text { protein, EGF, GC, Hya, Kun, LAAO, MYO, NGF, PDE, PLA 2, PLB, SVMP-P I/II/III, } \\
\text { SVSP, VEGF, vespryn }\end{array}$ & [75-87] \\
\hline C. aquilus & Hya, PLA 2 , SVMP P-III, SVSP (TLE) & {$[59,69]$} \\
\hline C. atrox & BIPs, BPPs, CNP, CRiSP, Dis, Hya, LAAO, CTL, PLA 2, SVMP P-I/III, SVSP, VEGF & {$[6,44,80,88-95]$} \\
\hline C. basiliscus & $\begin{array}{c}\text { BPP, CRISP, CTL, Dis, LAAO, PLA } 2 \text { (CRTX, non-CRTX), SVMP P-I/II/III, SVMP } \\
\text { inhibitor, SVSP }\end{array}$ & [96-99] \\
\hline C. catalinesis & SVSP, SVMP P-III, PLA 2 & [40] \\
\hline C. cerastes & $\begin{array}{l}\text { 3FTx, 5'NT, BPP, CRiSP, CTL, Dis, ficolin, Hya, Kun, LAAO, MYO, NGF, PDE, PLA } 2 \\
\text { SVMP P-II/III, SVSP, VEGF, vespryn, WAP }\end{array}$ & {$[98,100-102]$} \\
\hline C. durissus & $\begin{array}{l}\text { 3FTx, achase, aminopeptidase, angiogenin, BPP, carboxypeptidase, CNP, CRiSP, } \\
\text { CTL, CysProt inhibitor, CysProt, dipeptidyl peptidase, Dis, FGF, fraction 5, Hya, } \\
\text { Kazal, Kun, LAAO, lipase, MYO, NGF, PDGF, PLA } 2 \text { (non-CRTX, CRTX), PLB, PLD, } \\
\text { Serpin-like, SVMP inhibitor, SVMP P-III, SVSP, VEGF, vespryn, WAP }\end{array}$ & {$[45,64,103-118]$} \\
\hline C. enyo & SVSP, SVMP P-I/III, PLA 2 & {$[40]$} \\
\hline C. horridus & $\begin{array}{l}\text { 5'-NT, BPP, CNP, CRiSP, Dis, EGF-like, GC, Hya, Kun, LAAO, MYO, neurotrophic } \\
\text { factor, NGF, PDE, PLA } 2 \text {, SVMP P-I/III, SVSP, VEGF, vespryn }\end{array}$ & {$[29,119,120]$} \\
\hline C. lepidus & 5'NT, CRiSP, CTL, Dis, LAAO, PDE, PLA 2, SVMP-P-I/III, SVSP (TLE, kallikrein) & {$[49,121-123]$} \\
\hline C. mitchelli & LAAO, SVSP, PLA 2 (CRTX/MTX) & {$[40,124,125]$} \\
\hline C. molossus & Dis, LAAO, MYO, PLA 2, SVMP P-I/III, SVSP (TLE) & {$[58,98,126-130]$} \\
\hline C. oreganus & $\begin{array}{l}\text { ANP / BNP, BPP, CNP, CRiSP, CTL, Dis, Hya, Kun, LAAO, MYO, NGF, PLA2 (D49), } \\
\text { PLA } 2 \text {, SVMP P-II/III, SVSP, VEGF, vespryn }^{2}\end{array}$ & {$[51,56,57,131-137]$} \\
\hline C. polystictus & $\begin{array}{l}\text { BIPs, CRiSPs, CTL, Dis, GC, Hya, LAAO, NGF, PDE, PLA } 2 \text {, PLB, SVMP P-I/II/III, } \\
\text { SVSP (kallikrein, TLE), vespryn }\end{array}$ & {$[48,69]$} \\
\hline C. ruber & CTL, Dis, LAAO, PDE, PLA2, SVMP P-I/III, SVSP (kallikrein) & {$[40,47,138-143]$} \\
\hline C. scutulatus & $\begin{array}{l}\text { 5'-NT, APase, BPPs, CRiSP, CTL, Dis, Hya, Kun, LAAO, MYO, NGF, PDE, PLA } 2 \\
\text { (MTX, non-CRTX), SVMP P-I/II/III, SVSP, VEGF, vespryn }\end{array}$ & {$[41,52,63,144-148]$} \\
\hline C. simus & $\begin{array}{l}\text { 3FTX, 5'-NT, BIPs, BPPs, CRiSP, CTL, Dis, GC, Hya, Kaz, Kun, LAAO, MYO, NGF, } \\
\text { OHA, PDE, PLA } 2 \text { (CRTX, non-CRTX), PLB, SVMP P-I/III, SVSP, VEGF, WAP }\end{array}$ & {$[7,54,68,149-151]$} \\
\hline C. tigris & CRiSP, Dis, PLA 2 (MTX), SVMP P-III, SVSP, VEGF & {$[55,152-154]$} \\
\hline C. vegrandis & $\begin{array}{l}\text { 5'-NT, ATPase, BIP, BPP, carboxypeptidase, CNP, CRiSP, CTL, Dis, endonuclease } \\
\text { (DNAse, RNAse), exendin4-like protein, glutathione peroxidase, Hya, LAAO, MYO, } \\
\text { NGF, PDE, PLA } 2 \text { (CRTX), PLB, SVMP P-II/III, SVSP }\end{array}$ & {$[77,155-159]$} \\
\hline C. viridis & $\begin{array}{l}\text { 5'-NT, APase, BPP, CRiSP, CTL, Dis, GC, LAAO, MYO, OHA, PDE, PLA } 2 \text { (CRTX, } \\
\text { non-CRTX), PLB, SVMP inhibitor, SVMP P-I/II/III, SVSP (TLE, kallikrein) }\end{array}$ & {$[42,60-62,160-163]$} \\
\hline
\end{tabular}


Table 1. Cont.

\begin{tabular}{|c|c|c|}
\hline Species & Venom Components & Reference \\
\hline C. willardi & CRiSP, CTL, Dis, LAAO, PDE, PLA2, SVMP P-I/III, SVSP (TLE, kallikrein) & {$[49,153]$} \\
\hline C. tortugenesis & $\mathrm{N} / \mathrm{A}$ & \\
\hline C. stejnegeri & $\mathrm{N} / \mathrm{A}$ & \\
\hline C. tancitarensis & $\mathrm{N} / \mathrm{A}$ & \\
\hline C. lannomi & $\mathrm{N} / \mathrm{A}$ & \\
\hline C. pusillus & $\mathrm{N} / \mathrm{A}$ & \\
\hline C. transversus & $\mathrm{N} / \mathrm{A}$ & \\
\hline C. triseriatus & $\mathrm{N} / \mathrm{A}$ & \\
\hline C. unicolor & $\mathrm{N} / \mathrm{A}$ & \\
\hline C. intermedius & $\mathrm{N} / \mathrm{A}$ & \\
\hline
\end{tabular}

Note: three-finger toxin (3FTx), $5^{\prime}$-nucleotidase $\left(5^{\prime}-\mathrm{NT}\right)$, acetylcholinesterase (achase), natriuretic peptide type A (ANP), adenosine triphosphatase (ATPase), bradykinin inhibitory peptide (BIP), natriuretic peptide type B (BNP), bradykinin potentiate peptide (BPP), C-type lectins (CTL), natriuretic peptide type C (CNP), cysteine protease (CysProt), cysteine-rich secretory protein (CRiSP), crotoxin (CRTX), disintegrin (Dis), epidermal growth factor (EGF), fibroblast growth factor (FGF), guanylyl cyclase (GC), hyaluronidase (Hya), kazal-type inhibitor (Kazal), Kunitz-type inhibitor (Kun), L-amino acid oxidase (LAAO), Mojave toxin (MTX), myotoxin (MYO), nerve growth factor (NGF), ohanin (OHA), phosphodiesterase (PDE), platelet-derived growth factor (PDGF), phospholipase $\mathrm{A}_{2}$ (PLA $\mathrm{P}_{2}$ ), phospholipase B (PLB), phospholipase D (PLD), snake venom metalloprotease (SVMP), snake venom serine protease (SVSP), thrombin-like enzyme (TLE), vascular endothelial growth factor (VEGF), waparin (WAP).

\subsubsection{Frequency of Protein Components in Crotalus Venom}

The ubiquitous protein families in Crotalus venom are PLA 2 , SVMP P-III, SVSP, Dis, LAAO, CRiSP, CTL, SVMP P-I, BPP, Hya, and PDE (Figure 1).

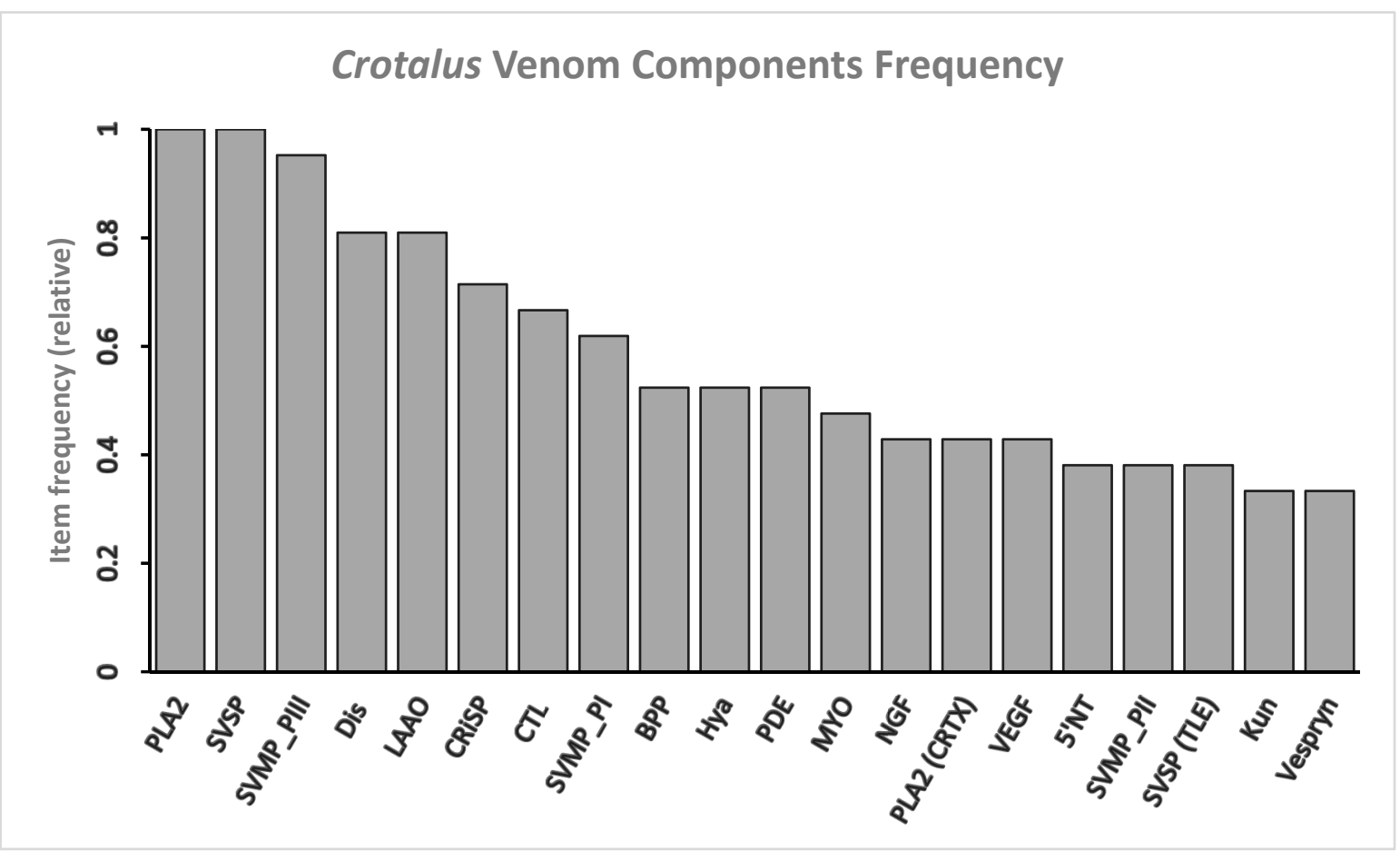

Figure 1. Twenty most common venom components in venom expressed by genus: Crotalus. PLA 2 and SVSP are identified as the most common among Crotalus species (relative frequency is 1$)$. Note: $5^{\prime}$-nucleotidase ( $5^{\prime}$-NT), bradykinin inhibitory peptide (BIP), bradykinin potentiate peptide (BPP), C-type lectins (CTL), natriuretic peptide type C (CNP), crotoxin (CRTX), disintegrin (Dis), guanylyl cyclase (GC), hyaluronidase (Hya), Kunitz-type inhibitor (Kun), L-amino acid oxidase (LAAO), myotoxin (MYO), nerve growth factor (NGF), phosphodiesterase (PDE), phospholipase $\mathrm{a}_{2}\left(\mathrm{PLA}_{2}\right)$, phospholipase b (PLB), snake venom metalloprotease (SVMP), snake venom serine protease (SVSP), vascular endothelial growth factor (VEGF). 


\subsubsection{Association between Various Venom Components in Crotalus Venom Using Presence/Absence Data}

Using the frequent item-set approach from data-mining literature [164], we identify a total of 559 relationships between different venom components for Crotalus (Table S1) (first three rules did not identify the predictor protein(s) and hence are discarded). See Box 1 for further discussion of terms associated with frequent item-set data-mining.

Box 1. Frequent item-set data-mining.

First introduced in 1993 [165], association rule mining has emerged as a popular technique in detecting and extracting key structural information from large-scale transaction data that is often generated in organizations, such as Krogers, Walmart, etc. [166]. These rules help the organizations understand the co-occurrence patterns and frequencies of various transactions, thus helping them become more efficient and profitable. By leveraging the similarity between the co-occurrence of protein components in venom, and transactions done by various shoppers in these supermarkets, we can use the powerful data-mining tools for discovering patterns in venom composition to boost the efficiency of biomedical research.

Let $I=\left\{i_{1}, i_{2}, i_{3}, \ldots, i_{n}\right)$ be a set of $n$ protein components (referred to as "items" in data-mining literature) and $D=\left\{t_{1}, t_{2}, t_{3}\right.$, $\left.\ldots, t_{n}\right\}$ be the set of venom samples. An association rule is defined as an implication of the form $X=>Y$ where $X, Y \subseteq I$ and $X \cap Y$ $=\varnothing$. The set of protein components (referred to as item sets) $X$ and $Y$ are called antecedent (left-hand side LHS or predictor) and consequent (right-hand side RHS or predicted) of the rule [167].

The support (supp) $(X)$ of itemset $X$ is defined as the proportion of venom samples in the data set which contain the itemset.

Confidence of a rule is defined as $\operatorname{conf}(X=>Y)=\operatorname{supp}(X \cup Y) /$ supp $(X)$ [167]. Confidence can be interpreted as an estimate of the probability $\mathrm{P}(\mathrm{Y} \mid \mathrm{X})$, the probability of finding RHS of the rule in the venom sample under the condition that these venom samples also contain LHS [167].

Lift of a rule is defined as $(X=>Y)=\operatorname{supp}(X \cup Y) /(\operatorname{supp}(X) \operatorname{supp}(Y))$. It can be interpreted as the deviation of the support of the whole rule from the support expected under independence given the supports of the LHS and RHS [167]. Greater lift values indicate stronger associations [167].

In this study, we highlight the top 20 associations (Figure 2), e.g., Dis is associated with CTL with a confidence of 1 and support of 0.667 (Table 2), implying that Dis and CTL are expressed together $66.7 \%$ times in venom of all species of Crotalus, and if CTL is expressed in venom, then Dis is expressed $100 \%$ times.

Crotalus' venom components are well studied to generate more than 500 associations, but only the top twenty relevant rules with at least 1 minor component are depicted in Table 2. If protein (predictor) is present in venom, then chances of the protein (predicted) to be expressed in the venom are given by combining "confidence" and "lift". Dis has the highest number of associations as a predicted component, which is 7: PDE, BPP, CRL, CRiSP, LAAO, SVMP P-I and LAAO, SVMP P-III and LAAO. Followed by LAAO with six associations: PDE, BPP, CTL, Dis and SVMP P-I, Dis, and CRiSP. On the other hand, CTL is associated with five groups, and CRiSP is represented by two associations. However, 5 associations of CTL have higher lift and confidence than LAAO's and Dis', indicating better associations.

2.1.3. Association between Various Venom Components in Crotalus Venom Using the Relative Abundance of Protein Components

A key challenge in inferring association between different species is the lack of data on relative abundance for venom components, e.g., for the Crotalus species, relative abundance is reported only for 14 out of the 30 species. Within these 14 species, relative abundance is reported for only $56.7 \%$ of the venom components. Using the limited data on relative abundances, we can identify a total of 47 association rules, also referred to as relationships between different venom components for Crotalus (Table S2). Herein we report only the top twenty relevant rules (Table 3, Figure 3).

Despite limited data, many relationships reported through presence/absence data are also reported through relative abundance data, such as CTL and LAAO, CTL and SVMPPIII, CTL and SVSP, BPP and LAAO, and CRiSP and LAAO. Through relative abundance data, we identified several new relationships, such as PLA 2 and SVMP_PIII, SVMP_PII and CTL, etc. (Figure 3). 
2.1.4. Hierarchical Clustering of Venom Components to Identify any Similarity or Dissimilarity with Phylogenetic Relationships

We used hierarchical clustering analysis of venom components with known relative abundances to cluster different Crotalus species according to the similarity in venom components (Figure 4). We found the clustering similar when we used maximum reported values of relative abundances for each venom component within a species to the average relative abundances of venom components within a species. One would expect similar venom composition in closely related species due to recent common ancestor, but such similarity was not observed. We conjecture that the reason different species have similar compositions is due to functional similarities. The venom composition of Crotalus durissus is different from the rest of the 14 species. Crotalus polystictus and Crotalus simus have similar venom composition, while Crotalus atrox, Crotalus bassilliscus, Crotalus tzabcan, Crotalus cerastes, Crotalus scutulatus, Crotalus viridis, Crotalus molossus, Crotalus vergandis, Crotalus tigris, Crotalus ruber, Crotalus horridus have similar venom composition (Figure 4).

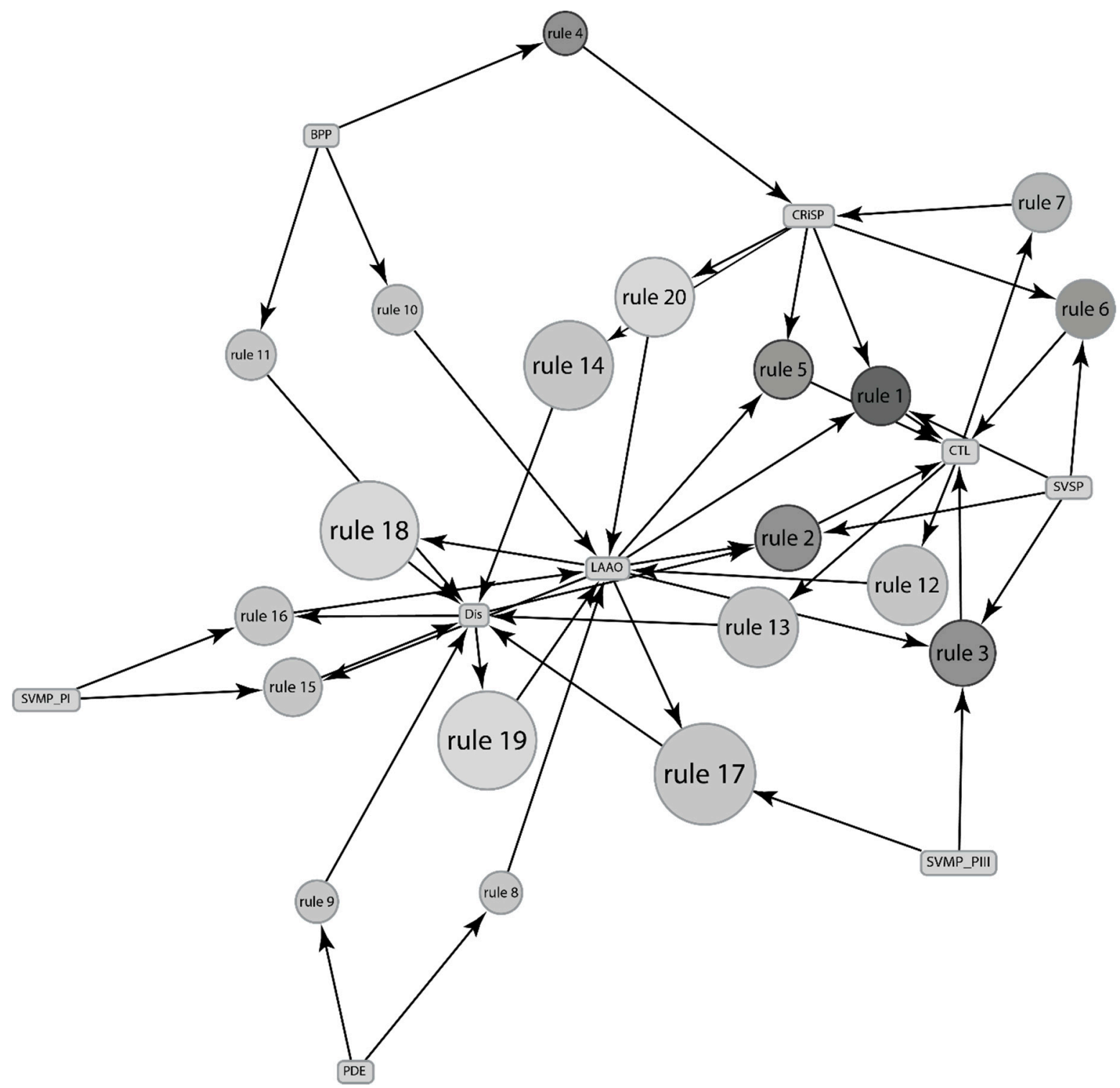

Figure 2. Depictions of association between components of venom expressed by genus Crotalus. The rules are depicted by the top twenty minor components-related rules as stated in Table 2. The size and the depth of color of the graph nodes are proportional to the support level and lift ratios of the underlying association rules. 
Table 2. Depictions of association rules between proteins expressed in Crotalus venom. Lift signifies the correlation between different venom components. Confidence shows the percentage in which the predicted venom component occurs with the predictor venom component. Support is the number of transactions in which the desired venom component occurs.

\begin{tabular}{|c|c|c|c|c|c|}
\hline Rule No. & Protein (Predictor) & Protein (Predicted) & Support & Confidence & Lift \\
\hline 1 & CRiSP, LAAO, SVSP & CTL & 0.61 & 1 & 1.5 \\
\hline 2 & Dis, LAAO, SVSP & CTL & 0.67 & 0.93 & 1.4 \\
\hline 3 & LAAO, SVMP P-III, SVSP & CTL & 0.67 & 0.93 & 1.4 \\
\hline 4 & $\mathrm{BPP}$ & CRiSP & 0.52 & 1 & 1.4 \\
\hline 5 & CRiSP, LAAO & CTL & 0.61 & 0.92 & 1.39 \\
\hline 6 & CRiSP, SVSP & CTL & 0.61 & 0.92 & 1.39 \\
\hline 7 & CTL & CRiSP & 0.61 & 0.92 & 1.3 \\
\hline 8 & PDE & LAAO & 0.52 & 1 & 1.23 \\
\hline 9 & PDE & Dis & 0.52 & 1 & 1.23 \\
\hline 10 & $\mathrm{BPP}$ & LAAO & 0.52 & 1 & 1.23 \\
\hline 11 & $\mathrm{BPP}$ & Dis & 0.52 & 1 & 1.23 \\
\hline 12 & CTL & LAAO & 0.67 & 1 & 1.23 \\
\hline 13 & CTL & Dis & 0.66 & 1 & 1.23 \\
\hline 14 & CRiSP & Dis & 0.71 & 1 & 1.23 \\
\hline 15 & LAAO, SVMP P-I & Dis & 0.57 & 1 & 1.23 \\
\hline 16 & Dis, SVMP P-I & LAAO & 0.57 & 1 & 1.23 \\
\hline 17 & LAAO, SVMP P-III & Dis & 0.76 & 1 & 1.23 \\
\hline 18 & LAAO & Dis & 0.76 & 0.94 & 1.16 \\
\hline 19 & Dis & LAAO & 0.76 & 0.94 & 1.16 \\
\hline 20 & CRiSP & LAAO & 0.67 & 0.93 & 1.15 \\
\hline
\end{tabular}

Note: $5^{\prime}$-nucleotidase (5'-NT), bradykinin potentiate peptide (BPP), C-type lectins (CTL), cysteine-rich secretory protein (CRiSP), disintegrin (Dis), L-amino acid oxidase (LAAO), nerve growth factor (NGF), phosphodiesterase (PDE), phospholipase $\mathrm{a}_{2}$ (PLA $\mathrm{PL}_{2}$, snake venom metalloprotease (SVMP), and snake venom serine protease (SVSP).

Table 3. Using maximum values of relative abundances of venom components, the association rules between proteins expressed in Crotalus venom. Lift signifies the correlation between different venom components. Confidence shows the percentage in which the predicted venom component occurs with the predictor venom component. Support is the number of transactions in which the desired venom component occurs.

\begin{tabular}{|c|c|c|c|c|c|}
\hline Rules No. & Protein (Predictor) & Protein (Predicted) & Support & Confidence & Lift \\
\hline 1 & SVMP_PI & LAAO & 0.6 & 1 & 1.5 \\
\hline 2 & BPP, CRiSP & LAAO & 0.6 & 1 & 1.5 \\
\hline 3 & CRiSP, CTL & LAAO & 0.67 & 1 & 1.5 \\
\hline 5 & CRiSP, CTL & SVMP_PI & 0.6 & 0.9 & 1.5 \\
\hline 6 & CTL & $\mathrm{BPP}$ & 0.67 & 0.9 & 1.36 \\
\hline 7 & CTL & LAAO & 0.67 & 0.9 & 1.36 \\
\hline 8 & CRiSP & LAAO & 0.67 & 0.9 & 1.36 \\
\hline 9 & SVMP_PI & CTL & 0.6 & 1 & 1.36 \\
\hline 10 & SVMP_PI & CRiSP & 0.6 & 1 & 1.36 \\
\hline 14 & SVMP_PII, SVMP_PIII & CTL & 0.53 & 1 & 1.36 \\
\hline 15 & CTL, SVMP_PII & SVMP_PIII & 0.53 & 1 & 1.36 \\
\hline 16 & SVMP_PII, SVSP & SVMP_PIII & 0.53 & 1 & 1.36 \\
\hline 17 & SVMP_PII, SVSP & CTL & 0.53 & 1 & 1.36 \\
\hline 18 & $\mathrm{BPP}$ & LAAO & 0.6 & 0.9 & 1.35 \\
\hline 20 & PLA2(Other), SVSP & SVMP_PIII & 0.73 & 0.91 & 1.25 \\
\hline 21 & PLA2(Other), SVSP & $\mathrm{CTL}$ & 0.73 & 0.91 & 1.25 \\
\hline 22 & PLA2(Other), SVSP & CRiSP & 0.73 & 0.91 & 1.25 \\
\hline 23 & SVMP_PIII & CTL & 0.67 & 0.9 & 1.23 \\
\hline 25 & SVMP_PIII & CRiSP & 0.67 & 0.9 & 1.23 \\
\hline 26 & CRiSP & SVMP_PIII & 0.67 & 0.9 & 1.24 \\
\hline
\end{tabular}

Note: $5^{\prime}$-nucleotidase (5'-NT), bradykinin potentiate peptide (BPP), C-type lectins (CTL), cysteine-rich secretory protein (CRiSP), disintegrin (Dis), L-amino acid oxidase (LAAO), nerve growth factor (NGF), phosphodiesterase (PDE), phospholipase $\mathrm{a}_{2}$ (PLA ${ }_{2}$ ), snake venom metalloprotease (SVMP), and snake venom serine protease (SVSP). 


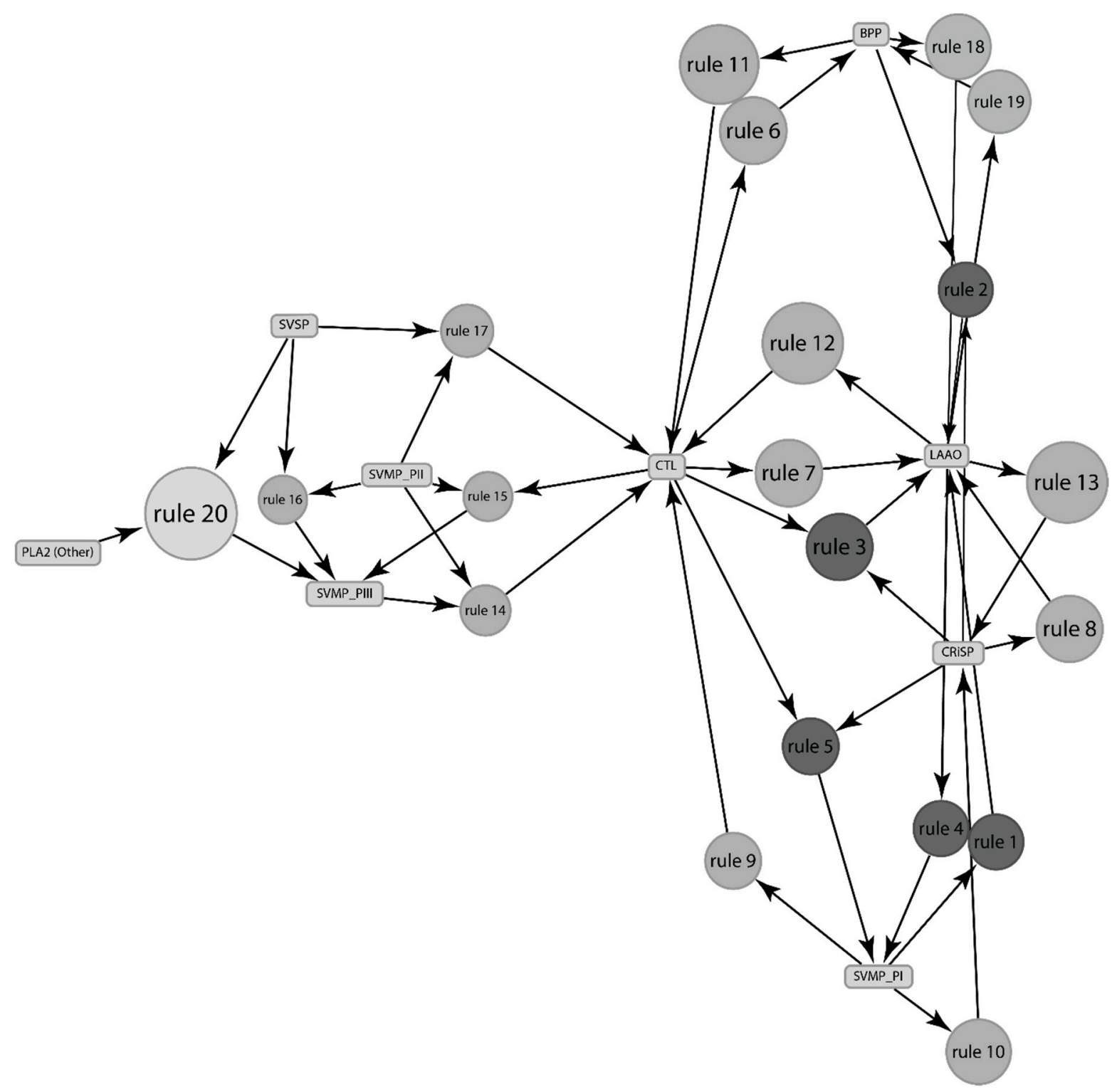

Figure 3. Using maximum values of relative abundances of the venom components, the association between components of venom expressed by genus Crotalus. The rules are depicted by the top 20 rules, as shown in Table 3 . The size and the depth of color of the graph nodes are proportional to the support level and lift ratios of the underlying association rules.

\subsection{Venom Constituents in Sistrurus Venom}

We identified compositional venom studies, through both transcriptomic and proteomic technologies, for 34 entries, including species and subspecies, within the genus Sistrurus. Few studies have focused on the Sistrurus subspecies' venom. 19 protein families are present in Sistrurus (Table 4). These protein families could be classified based on ubiquity or relationship with other proteins. 


\section{Dendrogram for Crotalus}

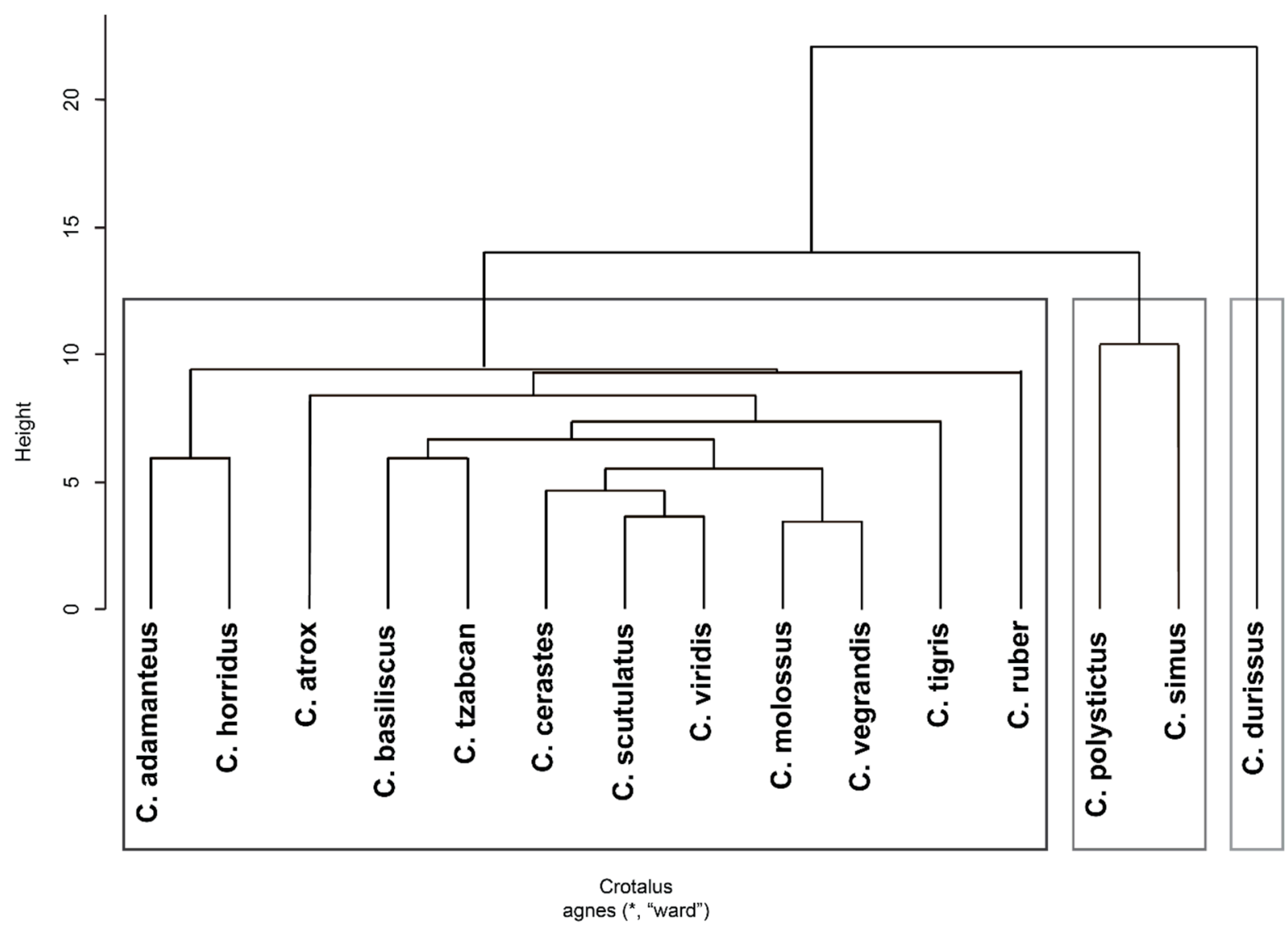

Figure 4. Hierarchical clustering of Crotalus species using maximum relative abundance values of known venom components.

* represents the dataset used for genetating this dendogram.

Table 4. Venom components in Sistrurus genus.

\begin{tabular}{|c|c|c|}
\hline Species & Venom Components & Reference \\
\hline S. catenatus & $\begin{array}{c}\text { 3FTx, 5'-NT, BPP, CNP, CRiSP, CTL, Dis, GC, LAAO, MYO, NGF, PDE, } \mathrm{PLA}_{2} \\
\text { (CRTX, non-CRTX), PLB, Renin-like Aspartic Protease, SVMP P-I/II/III, SVSP, } \\
\text { VEGF }\end{array}$ & {$[29,70,168-173]$} \\
\hline S. miliarius miliarius & BPP, CRiSP, CTL, Dis, NGF, PLA2, SVMP P-I/III, SVMP-inhibitor, SVSP & [71] \\
\hline S. miliarius streckeri & BPP, CRiSP, CTL, Dis, NGF, PLA, , SVMP P-I/III, SVMP-inhibitor, SVSP & [71] \\
\hline S. miliarius barbouri & BPP, CNP, CRiSP, Dis, PLA 2 , SVMP P-I/III, SVSP & {$[29,30,70,71,173-176]$} \\
\hline
\end{tabular}

Note: three-finger toxin (3FTx), $5^{\prime}$-nucleotidase (5'-NT), bradykinin potentiate peptide (BPP), C-type lectins (CTL), natriuretic peptide type $\mathrm{C}(\mathrm{CNP})$, cysteine-rich secretory protein (CRiSP), crotoxin (CRTX), disintegrin (Dis), guanylyl cyclase (GC), hyaluronidase (Hya), L-amino acid oxidase (LAAO), myotoxin (MYO), nerve growth factor (NGF), phosphodiesterase (PDE), phospholipase $\mathrm{a}_{2}$ ( $\mathrm{PLA}_{2}$ ), phospholipase $\mathrm{b}$ (PLB), snake venom metalloprotease (SVMP), snake venom serine protease (SVSP), and vascular endothelial growth factor (VEGF).

\subsubsection{Frequency of Protein Components in Sistrurus Venom}

The dominant protein families based on ubiquity in Sistrurus are BPP, CRiSP, Dis, SVMP, CTL, NGF, PLA 2 , and SVSP (Figure 4). The main difference between Crotalus and Sistrurus proteins is due to the absence of 27 venom components in Sistrurus (Figures 1 and 5). Some of the absent venom components from Sistrurus' proteomic and transcriptomic are: alkaline phosphomonoesterase (APase), acetylcholinesterase (achase), aminopeptidase, angiogenin, natriuretic peptide (ANP and BNP), ATPase, bradykinin inhibitory peptide (BIP), platelet-derived growth factor (PDGF), carboxypeptidase, cysteine protease (CysProt) and CysProt inhibitor, dipeptidase, dipeptidyl peptidase, EF-hand protein, epidermal 
growth factor (EGF), exendin4-like protein, endonuclease (DNAse and RNAse), fibroblast growth factor (FGF), ficolin/veficolin, glutathione peroxidase, hyaluronidase (Hya), Kazaltype inhibitor (Kazal), Kunitz-type inhibitor (Kun), lipase, ohanin (OHA), platelet-derived growth factor (PDGF), vespryn, phospholipase d (PLD), and waparin (WAP).

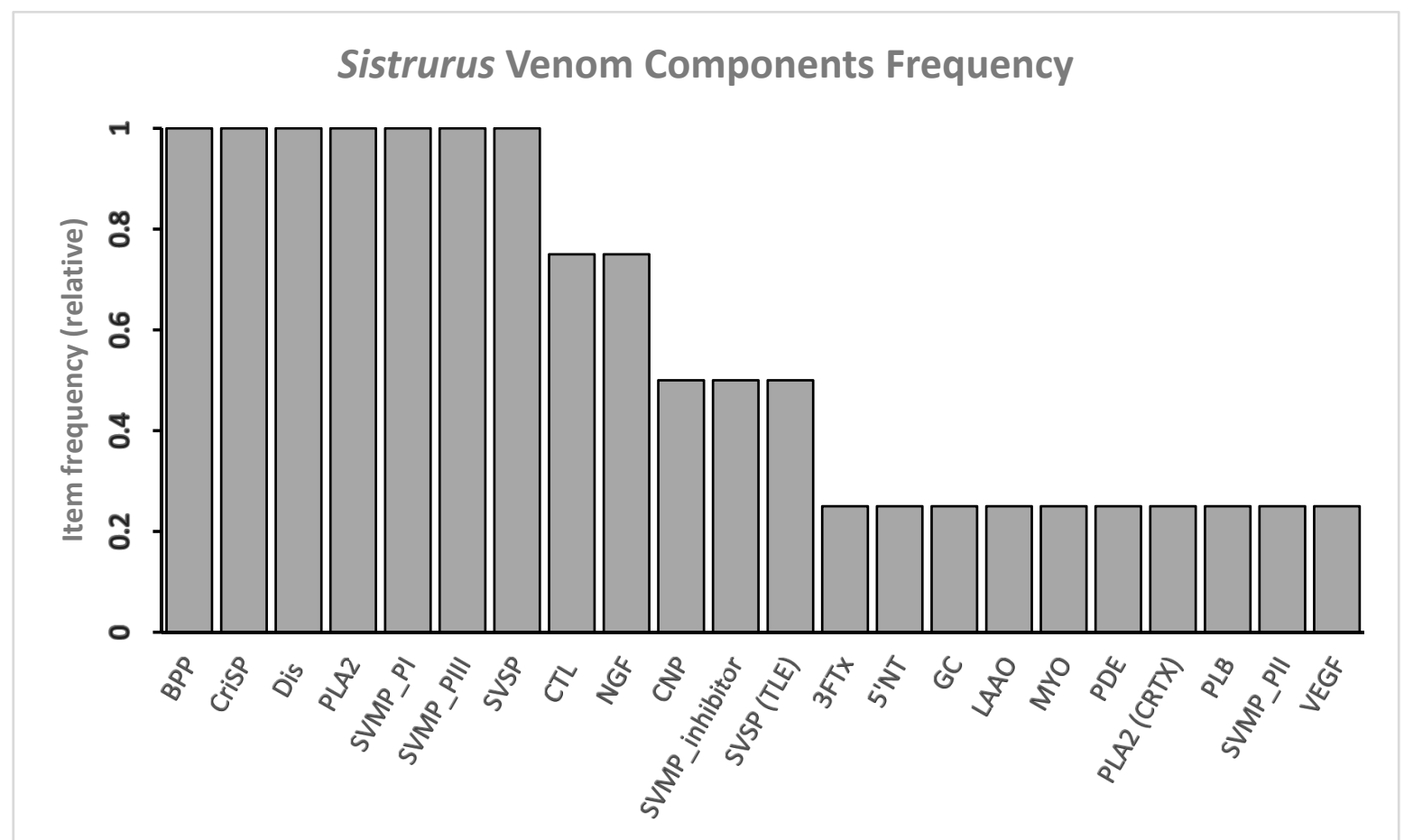

Figure 5. Twenty most common venom components in venom expressed by genus: Sistrurus. BPP, CRiSP, Dis, SVMP P-I/III are the most common toxins (relative frequencies are 1). Note: three-finger toxin (3FTx), $5^{\prime}$-nucleotidase ( $5^{\prime}$-NT), bradykinin potentiate peptide (BPP), C-type lectins (CTL), natriuretic peptide type C (CNP), cysteine-rich secretory protein (CRiSP), crotoxin (CRTX), disintegrin (Dis), guanylyl cyclase (GC), L-amino acid oxidase (LAAO), myotoxin (MYO), nerve growth factor (NGF), phosphodiesterase (PDE), phospholipase $\mathrm{a}_{2}\left(\mathrm{PLA}_{2}\right)$, phospholipase b (PLB), snake venom metalloprotease (SVMP), snake venom serine protease (SVSP), vascular endothelial growth factor (VEGF).

\subsubsection{Association between Various Venom Components in Sistrurus Venom Using Presence/Absence Data}

Using the frequent item-set data mining approach from data mining literature [164], we can identify eight relationships between different venom components for Sistrurus (Figure 6), e.g., NGF is associated with CTL with confidence $=1$, support $=0.75$ (Table 5), implying that NGF and CTL are expressed together $75 \%$ times in venom of all species of Sistrurus, and if NGF is expressed in venom, then $100 \%$ times CTL is also expressed. 


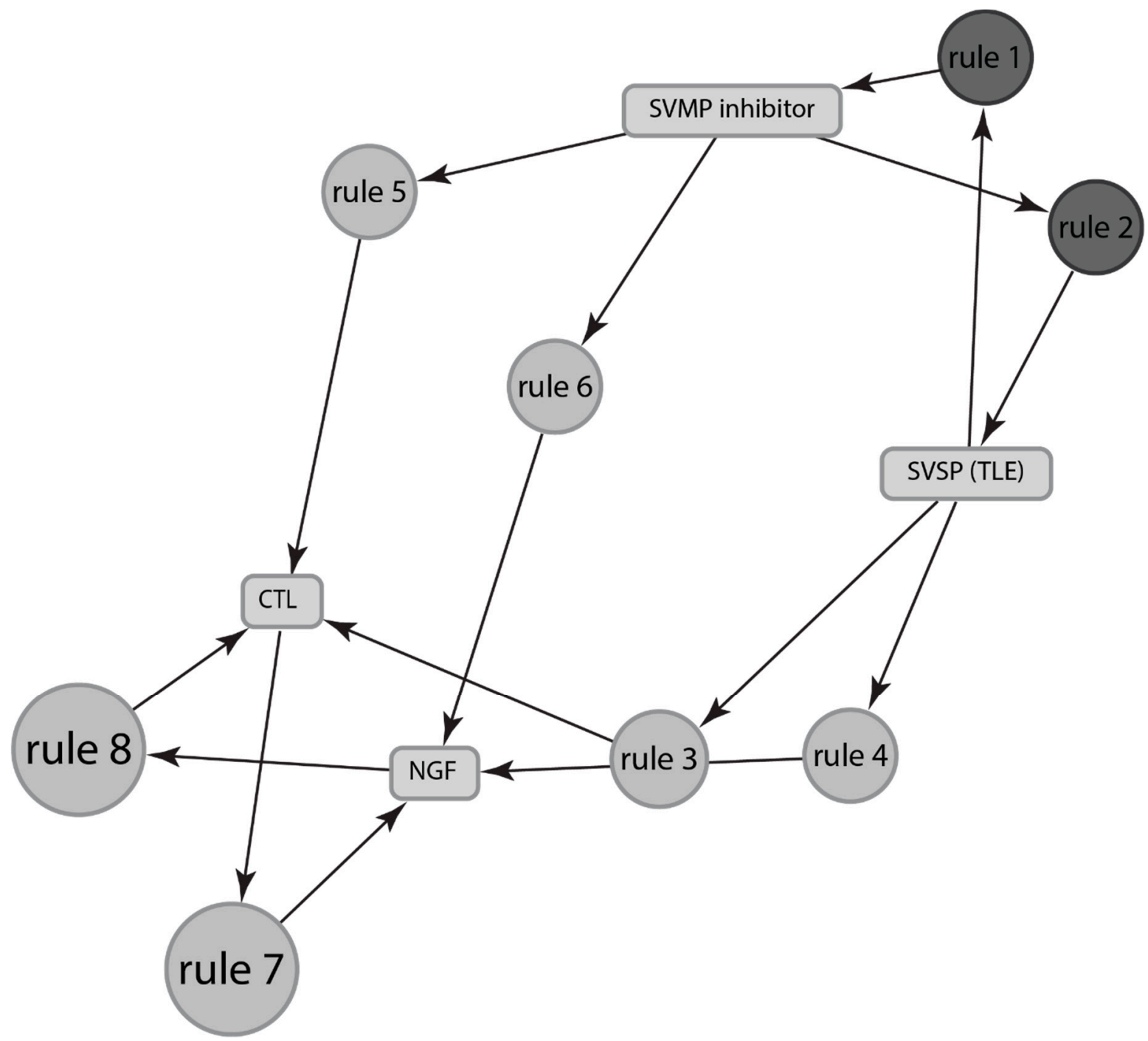

Figure 6. Depictions of association between components of venom expressed by genus Sistrurus. The rules are depicted by the top eight rules as stated in Table 5. The size and the depth of color of the graph nodes are proportional to the support level and lift ratios of the underlying association rules.

Table 5. Depictions of association rules between proteins expressed in Sistrurus venom. Lift signifies the correlation between different venom components. Confidence shows the percentage in which the predicted venom component occurs with the predictor venom component. Support is the number of transactions in which the desired venom component occurs.

\begin{tabular}{cccccc}
\hline Rules No. & Protein (Predictor) & Protein (Predicted) & Support & Confidence & Lift \\
\hline 1 & SVSP & SVMP inhibitor & 0.5 & 1 & 2 \\
2 & SVMP inhibitor & SVSP & 0.5 & 0.5 & 1 \\
3 & SVSP & CTL & 0.5 & 1 & 1.33 \\
4 & SVSP & NGF & 0.5 & 1 & 1.33 \\
5 & SVMP inhibitor & NGF & 0.5 & 1 & 1.33 \\
6 & SVMP inhibitor & NGF & 0.75 & 1 & 1.33 \\
7 & CTL & CTL & 0.75 & 1.33 \\
\hline
\end{tabular}

Note: C-type lectins (CTL), nerve growth factor (NGF), snake venom metalloprotease (SVMP), snake venom metalloprotease inhibitor (SVMP inhibitor), snake venom serine protease (SVSP). 
In contrast to Crotalus' venom components, studies on Sistrurus' venom component are lacking, and thus, only a small pool of studies are used to generate only eight associations, as depicted in Table 5. CTL and NGF each have three associations with different venom components. CTL is associated with NGF, SVMP inhibitor, and SVSP; NGF is associated with CTL, SVMP inhibitor, and SVSP. They are followed by SVMP inhibitor and SVSP with one association each: SVMP inhibitor is associated with SVSP and vice versa. However, SVMP inhibitor and SVSP's associations have higher lift and confidence than CTL's and NGF's, indicating better associations.

2.2.3. Association between Various Venom Components in Sistrurus Venom Using the Relative Abundance of Protein Components

Similar to Crotalus, a key challenge in inferring association between different species is the lack of data on relative abundance for venom components. There are only six studies that reported relative abundances for all species and subspecies within the genus Sistrurus. Relative abundance is reported for 21 out of 25 venom components. We identified a total of 13 associations (Table 6). Nine associations are discarded as they did not have any predictor component or are duplicates.

Table 6. Using maximum values of relative abundances of venom components, the association rules between proteins expressed in Sistrurus venom. Lift signifies the correlation between different venom components. Confidence shows the percentage in which the predicted venom component occurs with the predictor venom component. Support is the number of transactions in which the desired venom component occurs.

\begin{tabular}{cccccc}
\hline Rule No. & Protein Predictor & Protein (Predicted) & Support & Confidence & Lift \\
\hline 1 & SVMP_PIII & SVMP_PI & 0.5 & 1 & 2 \\
3 & SVMP_PIII & Vasoactive peptide & 0.5 & 1 & 2 \\
5 & SVMP_PI & Vasoactive peptide & 0.5 & 1 & 2 \\
7 & PLA2,CRTX & LAAO & 0.5 & 1 & 1.5 \\
8 & SVMP_PIII & BPP & 0.5 & 1 & 1.5 \\
9 & SVMP_PI & BPP & 0.5 & 1 & 1.5 \\
10 & Vasoactive peptide & BPP & 0.5 & 1 & 1.5 \\
11 & CNP & BPP & 0.5 & 1 & 1.5 \\
12 & PLA2,CRTX & CTL & 0.5 & 1 & 1.2 \\
13 & PLA2,CRTX & NGF & 0.5 & 1 & 1.2 \\
14 & LAAO & CTL & 0.67 & 1 & 1.2 \\
15 & LAAO & NGF & 0.67 & 1 & 1.2 \\
16 & CTL & NGF & 0.83 & 1 & 1.2 \\
\hline
\end{tabular}

Unlike presence/absence data, we found several new associations, such as PLA $_{2}$ associated with LAAO, CTL, and NGF; SVMP_PIII associated with SVMP_PI, Vasoactive peptide, and BPP, etc. (Table 6, Figure 7). 


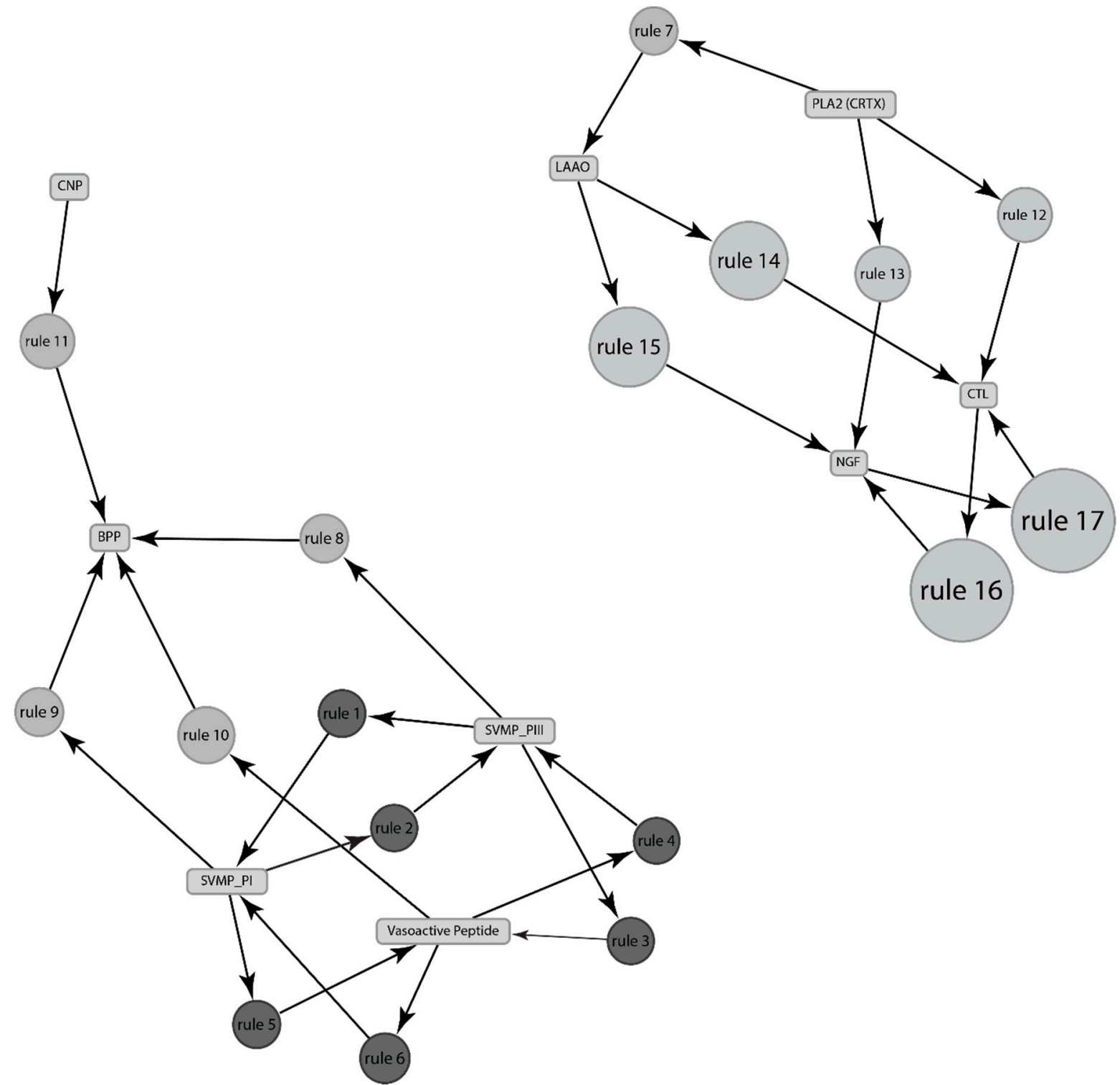

Figure 7. Using maximum values of relative abundances of the venom components, the association between components of venom expressed by genus Sistrurus. The size and the depth of color of the graph nodes are proportional to the support level and lift ratios of the underlying association rules. The rules are depicted by the top 13 rules as stated in Table 6 .

2.2.4. Hierarchical Clustering of Venom Components to Identify Similarities or Dissimilarities in Phylogenetic Relationships

Next, we use hierarchical clustering analysis of venom components with known relative abundances to cluster different Sistrurus species according to the similarity in venom components (Figure 8). One would expect similar venom composition in closely related species due to recent common ancestor, but such similarity is not observed. We conjecture that the reason different species have similar compositions is due to functional similarities. We found that the venom compositions of Sistrurus miliarius miliarius and Sistrurus miliarius strecki are similar. However, Sistrurus miliarius barbouri, phylogenetically similar to Sistrurus miliarius miliarius and Sistrurus miliarius strecki, does not have similar venom composition to these two subspecies of Sistrurus miliarius. Instead, its venom composition is similar to that of Sistrurus catenatus tergeminus and Sistrurus catenatus catenatus. Sistrurus catenatus edwardsii have a different venom composition than the other two subspecies (Figure 8). 
Dendrogram for Sistrurus

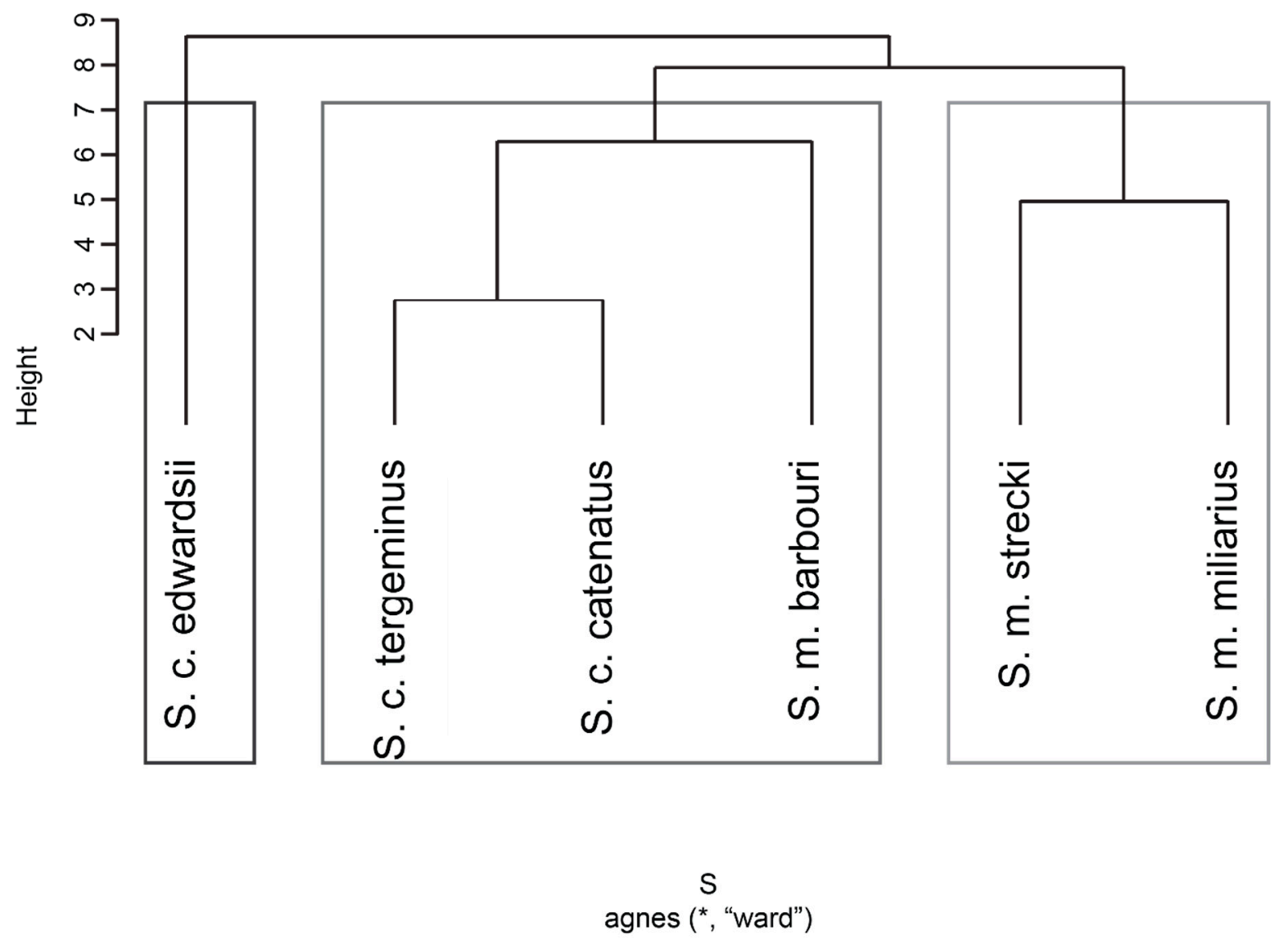

Figure 8. Hierarchical clustering of Sistrurus species using maximum relative abundance values of known venom components. ${ }^{*}$ represents the dataset used for genetating this dendogram.

\section{Discussion}

A total of 46 families of proteins are identified in the venom of 34 species and subspecies of rattlesnakes. Most studies focus on Crotalus, and a subset of studies focus on Sistrurus. Through our analysis, using the presence/absence of venom components, we can discover a total of 562 association rules for Crotalus and 25 association rules for Sistrurus venom components. In this study, we present the 20 most relevant rules for Crotalus and eight rules for Sistrurus venom components, respectively (Tables 2 and 5). Using the known relative abundances of venom components, we discovered 47 rules for Crotalus and 13 rules for Sistrurus venom components (Tables 3 and 6).

Using presence/absence data in developing venom component association only gives limited insight as venom becomes functionally different with changes in relative abundances of its components. However, we have been limited by existing information on the relative abundances of venom components. Within Crotalus, relative abundances have been reported for $46 \%$ of the species, and within these species, relative abundances have been reported for only $56 \%$ of venom components. Within Sistrurus, for all species and subspecies, relative abundances have been reported for $84 \%$ of venom components. Reporting relative abundances of different venom components would play a critical role in developing more insightful associations between different venom components.

There is an emphasis on investigating venom components stand-alone units with a lack of investigations of their relationships with each other and the subsequent effects of co-administering different components. On the other hand, understanding the relationship between venom components could open a new avenue for biomedical research 
and unlock protein combinations that yield enhanced bioactivity in pharmaceutical drugs. Additionally, studying components as stand-alone may have produced a negative effect in which many components have received skewed attention in biomedical research. For example, protein families are often classified as major or minor based on importance and ubiquity $[13,128]$. Thus, causing the dominant protein families, such as proteases, neurotoxins, and phospholipases, to be more researched than other protein families, such as growth factors. However, it is by combining ubiquity, bioactivity, and relationship between the protein families that we can classify the venom components as major or minor.

In rattlesnakes, MYO, PLA 2 , SVMP, and SVSP are classified as major components based on medical importance and ubiquity $[13,128]$, which is also confirmed by our analysis (Figure 1). However, with a new approach of using both ubiquity and number of associations for each protein, we find that Dis, LAAO, CTL are all more ubiquitous and have more associations with other proteins in Crotalus species (Table 2). Similarly, in Sistrurus species, the SVMP inhibitor and NGF (Figure 4) have the most associations than MYO, which has only one association (Table 3).

These associations play a critical role in the synergy between venom components [73]. This synergism causes the joint effects of multiple toxins to assert greater effects than the sum of individual potencies [73], making trace amount of snake venom to be highly efficient and effective $[73,74]$. Such combinations of venom proteins often cause various symptoms of bleedings, tissue degradation, necrosis, and further complications in prey and bite victims $[69,177]$ and improve the lethality of whole crude venom in contrast to individual components [73,178].

Through mostly studies of predominant toxins, different general mechanisms for toxin synergisms have been proposed [73,179]:

(1) Two or more toxins interact with different targets on related biological pathways, resulting in synergistically increased toxicity;

(2) Two or more toxins recognize and interact with the same target synergistically and produce the same effect, and is often called amplification;

(3) One toxin (subunit) acts as a chaperone to potentiate another one. The chaperone may expose the active/functional site of the second toxin (subunit), or expose target sites, or increase affinity to target or modify the active surface of the other toxin (subunit). Such complexes usually dissociate after asserting their toxicity.

Synergisms are mostly reported for major toxins in rattlesnake venoms [73]. A notable example of synergism through complex formation (mechanism 3) is crotoxin, a lethal neurotoxin from $C$. durissus terrificus, by two subunits: an acidic subunit component $A$ (CA or crotapotin) and a basic subunit component B (CB) $[109,115,116,180,181]$. CB is identified as a basic PLA 2 with phospholipase activities and low toxicity, while the CA component is said to be a small acidic, nonenzymatic, nontoxic subunit $[73,181]$. However, once combined non-covalently, $\mathrm{CA}$ improves the potency of $\mathrm{CB}$ by enabling $\mathrm{CB}$ to reach the specific crotoxin receptors at the neuromuscular junction as well as inhibits other CB functions, such as catalytic and anticoagulant activities $[115,181]$. Thus, the resulting crotoxin complex is highly active, compared to individual components, showing the synergy between two subunits blocking acetylcholine release [180,181]. Similarly, in C.

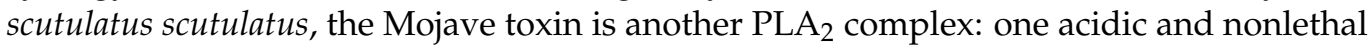
subunit acts as a chaperon for the other basic subunit to improves lethality $[41,148,162]$. Other examples of synergistic complexes have been found and reported in many species of Viperidae and Crotalidae [73]. Such interactions show the strong synergistic activities in rattlesnake venoms that have been studied intensively through previous endeavors.

A prevalent example between major components is SVMP P-III and an acidic PLA ${ }_{2}$ in Bothrops alternatus called baltergin and Ba SpII RP4 PLA 2 , respectively [182,183]. The more abundant PLA 2 has no myotoxic activities, while the less abundant baltergin possesses high edematogenic and myotoxic activities [182], while $\mathrm{PLA}_{2}$ has no myotoxicity, although it is the most abundant PLA 2 in this species [183]. When acting simultaneously, both can cause complete detachment of $C_{2} C_{12}$ myoblast cells, while none can achieve $50 \%$ 
of detachment on their own [184]. The analogous synergism has also been recorded in endothelial cells, SVMP's natural target $[73,185]$. The mechanism of synergism for such interaction is proposed through interactions with endothelial cells' membranes, free of catalysis rather than enzymatic activities of $\mathrm{PLA}_{2}$ [185]. Since PLA $\mathrm{PL}_{2}$ does not target extracellular matrix proteins like SVMP [182], indicating that the second general mechanism of toxin synergism is followed. Both enzymes are present in many rattlesnakes' venoms (Tables 1 and 3), and their association is also reported through our analysis (Table S1). There are reports indicating the synergism between crotoxin and crotamine, a member of MYO toxins in Crotalus venoms, which facilitates the internalization of the CB subunit and increases neuronal toxicity $[73,186]$. Unfortunately, these interactions are not found in the analysis (Table 2), although they are present in Crotalus venoms (Table 1), which could be due to the sparse reports on Crotalus' venoms with many species are still under-investigated as stated previously.

Even fewer studies focus on the synergism between major and minor components: SVSP, a major toxin, and BPPs, a minor toxin [73], indicating a biased approach in studying venom toxins produced by the current major/minor toxin classification convention. BPPs, which are micromolecular hypotensive peptides in snake venoms, can inhibit angiotensinconverting enzymes and induce hypotensive action of bradykinin, accompanied by hyperpermeability of blood vessels $[65,107,187,188]$. Thus, BPPs are targeted for many pharmaceutical developments to treat hypertension and heart failure $[189,190]$. On the other hand, many SVSPs show activities that are similar to kallikrein, a serine proteinase, with the specific and limited proteolytic functions that release bradykinin $[73,143,191]$. Previous works indicated that BPPs could act synergistically with kallikrein-like SVSPs, which release bradykinin more effectively than endogenous kallikrein to produce potent hypotension and vascular shock in prey $[73,95,143,192-194]$ (mechanism 1). Similarly, SVSP-BPP interaction results in a stronger physiological effect than from individual components. However, studies dedicated to understanding the mechanism and effects of such interactions are limited. The absence of such studies highlights the bias in current classification systems of major and minor venom components. Likewise, there are many components (e.g., LAAO) with substantial associations with other toxins, like CTL or NGF, that have not been investigated for their potential synergisms. Therefore, there is a need to develop a deeper understanding of minor components in the venom of rattlesnakes to discover more associations, such as that of SVSP and BPP.

Another way to explain the associations of these toxins is through the evolution of toxins. One relationship that has been explored in previous studies is between SVMP P-III and Dis. Dis is a small, nonenzymatic protein that can bind to extracellular receptors (integrins) with many motifs and sizes, two of which are RGD and MVD motifs $[9,68,144$, 195,196]. While SVMP-PIII is a subclass of SVMP with a Dis-like domain [197,198], Dis, especially the RGD/MVD motifs, is suggested to be produced from the rapid evolution of the genes coding of SVMP-PIII [195,196,199]. The RGD/MVD motifs of Dis are presented in many Crotalus species [195] along with SVMP-PIII, represent as rule 17 (Table 2) can be explained through this evolution model, although the co-association with LAAO is still largely unknown.

Some associations may not need to be derived through their toxicity but could be explained through the proteins' housekeeping functions. The existence of SVMP inhibitor is thought to be a housekeeping molecule, despite its potential therapeutic activities, which helps neutralize the potent SVMP in the venom glands as a self-defense mechanism [200]. Yet, not many studies have been invested in this family, along with the lack of occurrence in many rattlesnake venoms, where high amounts of SVMP exist (Table 1), which indicates a knowledge gap that requires further investigations. Likewise, NGF is known for its ability to inhibit SVMP proteolysis in Viperidae [201,202]. However, growing evidence has suggested the plausibility of other mechanisms in which NGF can act as cytotoxic proapoptotic factors in tissues that do not have TrkA receptors [201,203,204]; or as ancillary functions, like Hya, to help with efficient absorption of venom component through the 
release of granules molecules (histamine, serotonin, etc.) $[179,201,205]$. Such large release can also have impactful consequences (anaphylaxis, bronchoconstriction, vasodilation, etc.) $[201,206]$. However, not many Crotalus species have NGF, as observed previously in Table 1, indicating yet another gap of knowledge in Crotalus venomics. Using SVMP as a common targeting model to explain the association of NGF and SVMP inhibitor (rule 6, Table 5) is promising, but due to the insufficient amount of information provided, such explanation warrants further attempts in co-administration testing to confirm.

Developing phylogenetic relationships between different species using venom composition would further explain the various associations between different venom components as two species can have similar venom composition due to recent common ancestor or functional reasons. The existing venom composition data is greatly insufficient for developing the phylogenetic tree (Figure 4). However, the hierarchical clusters developed using known relative abundances show a different relationship than the observed phylogenetic relationships [207]. Even though C. durissus is similar to C. basiliscus, the venom composition of the latter is much more similar to that of $C$. molossus. The venom composition of $C$. durissus is unique compared to other species (Figure 4). Similar patterns can be observed with Sistrurus species (Figure 8). The possible explanations for this may be either functional similarity or insufficient data. However, one would expect the cluster structure to change with changes in venom composition due to age, sex, diet $[17,18,24,25]$, or topographical features $[26,27]$. We did not observe any difference between clusters built using the maximum relative abundance value or the average values. However, this result should be taken with caution as only a few studies reported multiple relative abundance values for some of the venom components. Thus, to have a deeper insight into the venom associations and venom component relationships, relative abundances must be quantified and reported.

\section{Conclusions}

In this paper, we have elicited the associations between different venom components. Thus, expediting future research on the synergy between various venom components. We also establish the need to report relative abundances for different venom components to increase the accuracy of the predicted associations and the understanding of venom evolution.

The results of this study suggest a myriad of associations, many of which are yet to be discovered, but they do provide promising potential synergistic effects that are worth further investigation. For example, using rules 2 and 13 in Crotalus venoms (Table 2), CTL, a protein/glycoprotein that specifically binds to carbohydrate moieties and glycoconjugate, can target and interact with platelet receptors and blood coagulation factors [208], which are also targets for Dis [209], indicate their potential synergisms with antiplatelet toxins and assert the hypotensive results along with many other toxin groups like SVSP [73, 95,143,192-194]. Thus, highlighting the importance of characterizing toxin components and their associations [69]. With an increased amount of characterization studies, novel families may also be correctly added into the venom profiles, such as three-finger toxins (3FTx), which often are present in elapids and a few occasions in rattlesnakes genome and transcriptome [14-16,169,171]. However, attention should be paid to developing venom profiles for understudied genera (Sistrurus) or species. Additionally, this work also addresses the problem of conventional classification of venom toxins as major or minor based on importance and ubiquity, which are often MYO, PLA 2 , SVMP, and SVSP [13,128], as the cause of much more attention on these dominant toxin families and overlooking other protein families, such as Growth factors. Therefore, we highlight the importance of studying venom components not only as individual components but also in understanding the relationship between them. We propose using the combination of toxin's characteristics, such as its ubiquity, bioactivity, and associations with other toxin families, to classify the venom components as major or minor. 


\section{Materials and Methods}

We collected articles and abstracts on venom for each Crotalus and Sistrurus species through the following: databases (PubMed, ScienceDirect, Scopus, Google Scholar, Web of Science), journal's databases (BMC Genomics, Journal of Proteome Research, Journal of Proteomics, Toxicon, Toxicology, Toxins), publisher databases (Wiley Online Library, MDPI, Elsevier). We used "venom" OR "proteomic" OR "venomic" OR "transcriptome" OR "proteome" AND "name of the species" as keywords for conducting our search. We also examined references in studies produced from the search results for any additional information. Collected records were the earliest obtainable records to those that are published in January of 2020.

From collected records, any article that did not contain information regarding venom composition and components of any Crotalus and Sistrurus species was not used in the current analysis. Otherwise, the articles' full-text version would be further assessed with the following inclusion and exclusion criteria.

For the article to be included in the current analysis, it had to fulfill one of the following inclusion criteria: (1) report proteome or transcriptome profile of the venom of any corresponding species; (2) report at least 1 toxin family/component, which is not artificially synthesized based on another similar toxin component; (3) be a comparative study reporting transcriptome/proteome profile for Crotalus, Sistrurus species/subspecies; (4) studies that report variability in venom components for any Crotalus, Sistrurus species/subspecies.

The following exclusion criteria were used to exclude any study from the current analysis: (1) reviews that focus on toxin families and/or articles focuses on the genomic evolution of toxin families; (2) articles with no transcriptome/proteome profiles; (3) articles with no data on toxin family isolated from venom; (4) articles that focus on new artificially synthesized molecules, based on similar toxin component or recombinant protein/peptides in venom; (5) articles reporting methods to inactivate toxin family from rattlesnakes; (6) case study on rattlesnakes' bites; (7) studies describing methods to detect toxin families/components. From the studies that fulfilled our inclusion criteria and did not meet any exclusion criteria, we collected and compiled all venom constituents that are reported for each species in the genus Crotalus and Sistrurus in Tables 1 and 4 respectively. The compiled data were cross-checked by authors for correctness and confirmations.

Using the data from Tables 1 and 4, we performed two separate frequent item-set data mining analyses for Crotalus and Sistrurus venoms. We conducted frequent item-set data mining using presence-absence data and a separate analysis using relative abundance values. In the analysis using relative abundance values, when more than one value for relative abundance was reported for a particular protein, we used the maximum value of relative abundances reported. There was no major difference in the results when we used maximum reported values versus the average of all reported values for a particular protein. For all values that are reported as below the limit of detection, we used the limit of detection as the value for that particular component [210]. Frequent item-set data mining helps identify the association rules associated with the expression of different proteins in venom. Studies on Sistrurus venom components are sparse, thus, can introduce a bias towards data-mining analysis. The rules specify the confidence, lift, and support for specific proteins to occur together in venom. Support is defined as absolute frequency, i.e., a support of $25 \%$ means that venom components $x, y$, and $z$ occur together in $25 \%$ of all venoms. Confidence is correlative frequency., i.e., a confidence of $60 \%$ means that if $x$ and $y$ occur, then $60 \%$ of times $z$ will also occur. Lift signifies the likelihood of the $y$ occurring when $x$ occurs while taking into account the number of times venom component $\mathrm{y}$ occurs in different species. An association rule is valid only if the lift is greater than 1. The higher the value of the lift, the higher is the validity of the rule. Since many studies associated with rattlesnake venom concentrated on highly abundant species or species containing more "major components", this affects the performance of the statistical models due to the presence of null values. For the analysis using only the presence-absence data for toxin families from individual studies, the chances of bias from individual studies 
affecting our results were low. With the increase in venom composition and variation data, the associations produced by frequent item-set data-mining analysis will be more informative. Using the relative abundance data of venom components from Tables 1 and 4, we performed hierarchical clustering for both Crotalus and Sistrurus species. For species with multiple values reported for the same venom component, we used the maximum of all reported values in our analysis. All analysis was performed using the software R ( $R$ Core Team, Vienna, Austria, 2019).

Supplementary Materials: The following are available online at https:/ /www.mdpi.com/article/10 $.3390 /$ toxins13060372/s1, Table S1: Depictions of full association rules between proteins expressed in Crotalus venom using presence/absence data. Table S2: Depictions of all association rules between proteins expressed in Crotalus venom using relative abundance data.

Author Contributions: Conceptualization, A.D.; methodology, A.D. and J.D.; validation, A.D. and P.P.; formal analysis, A.D. and J.D.; investigation, A.D. and P.P.; resources, S.K.T.; data curation, A.D. and P.P.; writing—original draft preparation, A.D. and P.P.; writing—review and editing, P.P., A.D., J.D., R.K. and S.K.T.; visualization, A.D. and J.D.; supervision, S.K.T.; project administration, S.K.T. and R.K. All authors have read and agreed to the published version of the manuscript.

Funding: This study was supported by grants from the National Institutes of Health (R01 CA172631/CA/NCI \& P30 GM103450/GM/NIGMS) and the Department of Energy (DE-FG02-01ER15161) and the National Science Foundation [grant number DMS-2015460 to J.D.].

Data Availability Statement: Data sharing not applicable.

Acknowledgments: We are thankful to Pooja Panwar, University of Arkansas, Fayetteville, the Department of Biological Sciences, Department of Biochemistry, and The University of Arkansas, Fort Smith.

Conflicts of Interest: The authors declare no conflict of interest.

$\begin{array}{ll}\text { Abbreviations } \\ \text { The following abbreviations are used in this manuscript: } \\ \text { 3FTx } & \text { Three-finger toxin } \\ 5^{\prime} \text {-NT } & \text { 5'-nucleotidase }^{\prime} \\ \text { Achase } & \text { Acetylcholinesterase } \\ \text { ANP } & \text { Natriuretic peptide type A } \\ \text { ATPase } & \text { Adenosine triphosphatase } \\ \text { BIP } & \text { Bradykinin inhibitory peptide } \\ \text { BNP } & \text { Natriuretic peptide type B } \\ \text { BPP } & \text { Bradykinin potentiate peptide } \\ \text { CTL } & \text { C-type Lectins } \\ \text { CNP } & \text { Natriuretic peptide type C } \\ \text { CysProt } & \text { Cysteine protease } \\ \text { CRiSP } & \text { Cysteine-rich secretory protein } \\ \text { CA } & \text { Crotapotin } \\ \text { CRTX } & \text { Crotoxin } \\ \text { Dis } & \text { Disintegrin } \\ \text { EGF } & \text { Epidermal growth factor } \\ \text { FGF } & \text { Fibroblast growth factor } \\ \text { GC } & \text { Guanylyl cyclase } \\ \text { Hya } & \text { Hyaluronidase } \\ \text { Kazal } & \text { Kazal-type inhibitor } \\ \text { Kun } & \text { Kunitz-type inhibitor } \\ \text { LAAO } & \text { L-amino acid oxidase } \\ \text { MTX } & \text { Mojave toxin } \\ \text { MYO } & \text { Myotoxin } \\ \text { NGF } & \text { Nerve growth factor } \\ & \\ \end{array}$




$\begin{array}{ll}\text { OHA } & \text { Ohanin } \\ \text { PDE } & \text { Phosphodiesterase } \\ \text { PDGF } & \text { Platelet-derived growth factor } \\ \text { PLA }_{2} & \text { Phospholipase } A_{2} \\ \text { PLB } & \text { Phospholipase B } \\ \text { PLD } & \text { Phospholipase D } \\ \text { SVMP } & \text { Snake venom metalloprotease } \\ \text { SVSP } & \text { Snake venom serine protease } \\ \text { TLE } & \text { Thrombin-like enzyme } \\ \text { VEGF } & \text { Vascular endothelial growth factor } \\ \text { WAP } & \text { Waparin } \\ \text { N/A } & \text { No information available } \\ * & \text { Dataset used for generating hierarchical clusters }\end{array}$

\section{References}

1. Fry, B.G.; Wüster, W.; Kini, R.M.; Brusic, V.; Khan, A.; Venkataraman, D.; Rooney, A.P. Molecular evolution and phylogeny of elapid snake venom three-finger toxins. J. Mol. Evol. 2003, 57, 110-129. [CrossRef]

2. Adade, C.M.; Carvalho, A.L.O.; Tomaz, M.A.; Costa, T.F.R.; Godinho, J.L.; Melo, P.A.; Lima, A.P.C.A.; Rodrigues, J.C.F.; Zingali, R.B.; Souto-Padrón, T. Crovirin, a snake venom cysteine-rich secretory protein (CRISP) with promising activity against Trypanosomes and Leishmania. PLoS Negl. Trop. Dis. 2014, 8, e3252. [CrossRef]

3. Sanchez, E.E.; Galan, J.A.; Russell, W.K.; Soto, J.G.; Russell, D.H.; Perez, J.C. Isolation and characterization of two disintegrins inhibiting ADP-induced human platelet aggregation from the venom of Crotalus scutulatus scutulatus (Mohave Rattlesnake). Toxicol. Appl. Pharmacol. 2006, 212, 59-68. [CrossRef]

4. Suntravat, M.; Jia, Y.; Lucena, S.E.; Sánchez, E.E.; Pérez, J.C. cDNA cloning of a snake venom metalloproteinase from the eastern diamondback rattlesnake (Crotalus adamanteus), and the expression of its disintegrin domain with anti-platelet effects. Toxicon Off. J. Int. Soc. Toxinol. 2013, 64, 43-54. [CrossRef]

5. Suntravat, M.; Barret, H.S.; Jurica, C.A.; Lucena, S.E.; Perez, J.C.; Sánchez, E.E. Recombinant disintegrin (r-Cam-dis) from Crotalus adamanteus inhibits adhesion of human pancreatic cancer cell lines to laminin-1 and vitronectin. J. Venom Res. 2015, 6, 1-10. [PubMed]

6. Galán, J.A.; Sánchez, E.E.; Rodríguez-Acosta, A.; Soto, J.G.; Bashir, S.; McLane, M.A.; Paquette-Straub, C.; Pérez, J.C. Inhibition of lung tumor colonization and cell migration with the disintegrin crotatroxin 2 isolated from the venom of Crotalus atrox. Toxicon Off. J. Int. Soc. Toxinol. 2008, 51, 1186-1196. [CrossRef]

7. Mackessy, S.; Saviola, A.; Mukherjee, A. Venom toxins to drugs: Anti-thrombotic and anti-metastasis compounds from snake venoms. Toxicon 2018, 150, 320. [CrossRef]

8. Arruda Macedo, J.K.; Fox, J.W.; de Souza Castro, M. Disintegrins from snake venoms and their applications in cancer research and therapy. Curr. Protein. Pept. Sci. 2015, 16, 532-548. [CrossRef] [PubMed]

9. Da Silva, M.; Lucena, S.; Aguilar, I.; Rodriguez-Acosta, A.; Salazar, A.M.; Sanchez, E.E.; Giron, M.E.; Carvajal, Z.; Arocha-Pinango, C.L.; Guerrero, B. Anti-platelet effect of cumanastatin 1, a disintegrin isolated from venom of South American Crotalus rattlesnake. Thromb. Res. 2009, 123, 731-739. [CrossRef] [PubMed]

10. Fox, J.W.; Serrano, S.M. Approaching the golden age of natural product pharmaceuticals from venom libraries: An overview of toxins and toxin-derivatives currently involved in therapeutic or diagnostic applications. Curr. Pharm. Des. 2007, 13, 2927-2934. [CrossRef] [PubMed]

11. Lucena, S.E.; Romo, K.; Suntravat, M.; Sánchez, E.E. Anti-angiogenic activities of two recombinant disintegrins derived from the Mohave and Prairie rattlesnakes. Toxicon 2014, 78, 10-17. [CrossRef]

12. Urra, F.A.; Araya-Maturana, R. Targeting Metastasis with Snake Toxins: Molecular Mechanisms. Toxins 2017, 9, 390. [CrossRef]

13. Tasoulis, T.; Isbister, G.K. A Review and Database of Snake Venom Proteomes. Toxins 2017, 9, 290. [CrossRef]

14. Kumar, T.; Yang, P.; Lin, S.; Wu, C.; Lei, B.; Lo, S.; Tu, S.-C.; Yu, C. Cloning, Direct Expression, and Purification of a Snake Venom Cardiotoxin inEscherichia coli. Biochem. Biophys. Res. Commun. 1996, 219, 450-456. [CrossRef]

15. Kumar, T.; Jayaraman, G.; Lee, C.S.; Arunkumar, A.; Sivaraman, T.; Samuel, D.; Yu, C. Snake venom cardiotoxins-structure, dynamics, function and folding. J. Biomol. Struct. Dyn. 1997, 15, 431-463. [CrossRef]

16. Sivaraman, T.; Kumar, T.; Tu, Y.; Peng, H.; Yu, C. Structurally homologous toxins isolated from the Taiwan cobra (Naja naja atra) differ significantly in their structural stability. Arch. Biochem. Biophys. 1999, 363, 107-115. [CrossRef] [PubMed]

17. Daltry, J.C.; Wuster, W.; Thorpe, R.S. Diet and snake venom evolution. Nature 1996, 379, 537-540. [CrossRef] [PubMed]

18. Fry, B.G.; Wickramaratna, J.C.; Hodgson, W.C.; Alewood, P.F.; Kini, R.; Ho, H.; Wüster, W. Electrospray liquid chromatography/mass spectrometry fingerprinting of Acanthophis (death adder) venoms: Taxonomic and toxinological implications. Rapid Commun. Mass Spectrom. 2002, 16, 600-608. [CrossRef]

19. Assakura, M.T.; Salomao, M.G.; Puorto, G.; Mandelbaum, F.R. Hemorrhagic, fibrinogenolytic and edema-forming activities of the venom of the colubrid snake Philodryas olfersii (green snake). Toxicon 1992, 30, 427-438. [CrossRef] 
20. Jimenez Porras, J.M. Intraspecific variations in composition of venom of the jumping viper, bothrops nummifera. Toxicon 1964, 2, 187-195. [CrossRef]

21. Glenn, J.L.; Straight, R.C.; Wolfe, M.C.; Hardy, D.L. Geographical variation in Crotalus scutulatus scutulatus (Mojave rattlesnake) venom properties. Toxicon 1983, 21, 119-130. [CrossRef]

22. Yang, C.C.; Chang, L.S.; Wu, F.S. Venom constituents of Notechis scutatus scutatus (Australian tiger snake) from differing geographic regions. Toxicon 1991, 29, 1337-1344. [CrossRef]

23. Barlow, A.; Pook, C.E.; Harrison, R.A.; Wuster, W. Coevolution of diet and prey-specific venom activity supports the role of selection in snake venom evolution. Proc. Biol. Sci. 2009, 276, 2443-2449. [CrossRef] [PubMed]

24. Saravia, N.G.; Weigle, K.; Navas, C.; Segura, I.; Valderrama, L.; Valencia, A.Z.; Escorcia, B.; McMahon-Pratt, D. Heterogeneity, geographic distribution, and pathogenicity of serodemes of Leishmania viannia in Colombia. Am. J. Trop. Med. Hyg. 2002, 66, 738-744. [CrossRef]

25. Creer, S.; Malhotra, A.; Thorpe, R.S.; Stocklin, R.S.; Favreau, P.S.; Hao Chou, W.S. Genetic and ecological correlates of intraspecific variation in pitviper venom composition detected using matrix-assisted laser desorption time-of-flight mass spectrometry (MALDI-TOF-MS) and isoelectric focusing. J. Mol. Evol. 2003, 56, 317-329. [CrossRef]

26. Tonello, F.; Simonato, M.; Aita, A.; Pizzo, P.; Fernandez, J.; Lomonte, B.; Gutierrez, J.M.; Montecucco, C. A Lys49-PLA2 myotoxin of Bothrops asper triggers a rapid death of macrophages that involves autocrine purinergic receptor signaling. Cell Death Dis. 2012, 3, e343. [CrossRef]

27. Fry, B. Venomous Reptiles and Their Toxins: Evolution, Pathophysiology and Biodiscovery; Oxford University Press: New York, NY, USA, 2015.

28. Mackessy, S.P.; Sixberry, N.M.; Heyborne, W.H.; Fritts, T. Venom of the Brown Treesnake, Boiga irregularis: Ontogenetic shifts and taxa-specific toxicity. Toxicon Off. J. Int. Soc. Toxinol. 2006, 47, 537-548. [CrossRef]

29. Rokyta, D.R.; Margres, M.J.; Calvin, K. Post-transcriptional Mechanisms Contribute Little to Phenotypic Variation in Snake Venoms. G3 Genes Genomes Genet. 2015, 5, 2375-2382. [CrossRef]

30. Calvete, J.J.; Juarez, P.; Sanz, L. Snake venomics. Strategy and applications. J. Mass Spectrom. 2007, 42, 1405-1414. [CrossRef]

31. Cintra, A.C.O.; De Toni, L.G.B.; Sartim, M.A.; Franco, J.J.; Caetano, R.C.; Murakami, M.T.; Sampaio, S.V. Batroxase, a new metalloproteinase from B. atrox snake venom with strong fibrinolytic activity. Toxicon 2012, 60, 70-82. [CrossRef] [PubMed]

32. Fox, J.W. A brief review of the scientific history of several lesser-known snake venom proteins: L-amino acid oxidases, hyaluronidases and phosphodiesterases. Toxicon 2013, 62, 75-82. [CrossRef]

33. Kordis, D.; Gubensek, F. Adaptive evolution of animal toxin multigene families. Gene 2000, 261, 43-52. [CrossRef]

34. Moura-da-Silva, A.M.; Paine, M.J.I.; Diniz, M.R.V.; Theakston, R.D.G.; Crampton, J.M. The molecular cloning of a phospholipase A 2 from Bothrops jararacussu snake venom: Evolution of venom group II phospholipase A 2's may imply gene duplications. J. Mol. Evol. 2020, 41, 174-179. [CrossRef]

35. Slowinski, J.B.; Knight, A.; Rooney, A.P. Inferring species trees from gene trees: A phylogenetic analysis of the Elapidae (Serpentes) based on the amino acid sequences of venom proteins. Mol. Phylogenet. Evol. 1997, 8, 349-362. [CrossRef] [PubMed]

36. Afifiyan, F.; Armugam, A.; Tan, C.H.; Gopalakrishnakone, P.; Jeyaseelan, K. Postsynaptic $\alpha$-Neurotoxin Gene of the Spitting Cobra, Naja naja sputatrix: Structure, Organization, and Phylogenetic Analysis. Genome Res. 1999, 9, 259-266. [PubMed]

37. Chang, L.; Lin, S.; Huang, H.; Hsiao, M. Genetic organization of alpha-bungarotoxins from Bungarus multicinctus (Taiwan banded krait): Evidence showing that the production of alpha-bungarotoxin isotoxins is not derived from edited mRNAs. Nucleic. Acids Res. 1999, 27, 3970-3975. [CrossRef]

38. Kocholaty, W.F.; Ledford, E.B.; Daly, J.G.; Billings, T.A. Toxicity and some enzymatic properties and activities in the venoms of Crotalidae, Elapidae and Viperidae. Toxicon 1971, 9, 131-138. [CrossRef]

39. Campbell, J.A.; Lamar, W.W.; Brodie, E.D. The Venomous Reptiles of the Western Hemisphere; Comstock Pub. Associates: Ithaca, NY, USA, 2004; Volume 2.

40. Arnaud-Franco, G.; Cordero-Tapia, A.; Ortiz-Avila, V.; Moctezuma-Gonzalez, C.L.; Tejocote-Perez, M.; Carbajal-Saucedo, A. Comparison of biological and biochemical characteristics of venom from rattlesnakes in the southern Baja California Peninsula. Toxicon 2018, 148, 197-201. [CrossRef] [PubMed]

41. Borja, M.; Neri-Castro, E.; Castaneda-Gaytan, G.; Strickland, J.L.; Parkinson, C.L.; Castaneda-Gaytan, J.; Ponce-Lopez, R.; Lomonte, B.; Olvera-Rodriguez, A.; Alagon, A.; et al. Biological and Proteolytic Variation in the Venom of Crotalus scutulatus scutulatus from Mexico. Toxins 2018, 10, 35. [CrossRef]

42. Mackessy, S.P. Evolutionary trends in venom composition in the western rattlesnakes (Crotalus viridis sensu lato): Toxicity vs. tenderizers. Toxicon 2010, 55, 1463-1474. [CrossRef]

43. Findrik, Z.; Vasić-Rački, Đ.; Primožič, M.; Habulin, M.; Knez, Ž. Enzymatic activity of L-amino acid oxidase from snake venom Crotalus adamanteus in supercritical CO2. Biocatal. Biotransform. 2005, 23, 315-321. [CrossRef]

44. Calvete, J.J.; Fasoli, E.; Sanz, L.; Boschetti, E.; Righetti, P.G. Exploring the venom proteome of the western diamondback rattlesnake, Crotalus atrox, via snake venomics and combinatorial peptide ligand library approaches. J. Proteome Res. 2009 , 8, $3055-3067$. [CrossRef] [PubMed]

45. Boldrini-Franca, J.; Correa-Netto, C.; Silva, M.M.; Rodrigues, R.S.; De La Torre, P.; Perez, A.; Soares, A.M.; Zingali, R.B.; Nogueira, R.A.; Rodrigues, V.M.; et al. Snake venomics and antivenomics of Crotalus durissus subspecies from Brazil: Assessment of geographic variation and its implication on snakebite management. J. Proteom. 2010, 73, 1758-1776. [CrossRef] [PubMed] 
46. Costa, T.R.; Burin, S.M.; Menaldo, D.L.; de Castro, F.A.; Sampaio, S.V. Snake venom L-amino acid oxidases: An overview on their antitumor effects. J. Venom. Anim. Toxins Incl. Trop. Dis. 2014, 20, 23. [CrossRef]

47. Mackessy, S.P. Fractionation of red diamond rattlesnake (Crotalus ruber ruber) venom: Protease, phosphodiesterase, L-amino acid oxidase activities and effects of metal ions and inhibitors on protease activity. Toxicon 1985, 23, 337-340. [CrossRef]

48. Mackessy, S.P.; Leroy, J.; Mociño-Deloya, E.; Setser, K.; Bryson, R.W.; Saviola, A.J. Venom Ontogeny in the Mexican Lance-Headed Rattlesnake (Crotalus polystictus). Toxins 2018, 10, 271. [CrossRef]

49. Saviola, A.J.; Gandara, A.J.; Bryson, R.W., Jr.; Mackessy, S.P. Venom phenotypes of the Rock Rattlesnake (Crotalus lepidus) and the Ridge-nosed Rattlesnake (Crotalus willardi) from Mexico and the United States. Toxicon 2017, 138, 119-129. [CrossRef]

50. Komori, Y.; Sakai, K.; Masuda, K.; Nikai, T. Isolation and Biochemical Characterization of Rubelase, a Non-Hemorrhagic Elastase from Crotalus ruber ruber (Red Rattlesnake) Venom. Toxins 2011, 3, 900-910. [CrossRef] [PubMed]

51. Mackessy, S.P. Characterization of the major metalloprotease isolated from the venom of the northern pacific rattlesnake, Crotalus viridis oreganus. Toxicon 1996, 34, 1277-1285. [CrossRef]

52. Smith, C.F.; Mackessy, S.P. The effects of hybridization on divergent venom phenotypes: Characterization of venom from Crotalus scutulatus scutulatus $x$ Crotalus oreganus helleri hybrids. Toxicon 2016, 120, 110-123. [CrossRef]

53. Boldrini-Franca, J.; Pinheiro-Junior, E.L.; Arantes, E.C. Functional and biological insights of rCollinein-1, a recombinant serine protease from Crotalus durissus collilineatus. J. Venom. Anim. Toxins Incl. Trop. Dis. 2019, 25, e147118. [CrossRef]

54. Calvete, J.J.; Sanz, L.; Cid, P.; de la Torre, P.; Flores-Diaz, M.; Dos Santos, M.C.; Borges, A.; Bremo, A.; Angulo, Y.; Lomonte, B.; et al. Snake venomics of the Central American rattlesnake Crotalus simus and the South American Crotalus durissus complex points to neurotoxicity as an adaptive paedomorphic trend along Crotalus dispersal in South America. J. Proteome Res. 2010, 9 , 528-544. [CrossRef]

55. Calvete, J.J.; Perez, A.; Lomonte, B.; Sanchez, E.E.; Sanz, L. Snake venomics of Crotalus tigris: The minimalist toxin arsenal of the deadliest Nearctic rattlesnake venom. Evolutionary Clues for generating a pan-specific antivenom against crotalid type II venoms [corrected]. J. Proteome Res. 2012, 11, 1382-1390. [CrossRef]

56. Almeida, J.R.; Resende, L.M.; Silva, A.G.; Ribeiro, R.I.; Stabeli, R.G.; Soares, A.M.; Calderon, L.A.; Marangoni, S.; Da Silva, S.L. Biochemical and functional studies of ColTx-I, a new myotoxic phospholipase A2 isolated from Crotalus oreganus lutosus (Great Basin rattlesnake) snake venom. Toxicon 2016, 117, 1-12. [CrossRef] [PubMed]

57. Almeida, J.R.; Lancellotti, M.; Soares, A.M.; Calderon, L.A.; Ramirez, D.; Gonzalez, W.; Marangoni, S.; Da Silva, S.L. CoaTx-II, a new dimeric Lys49 phospholipase A2 from Crotalus oreganus abyssus snake venom with bactericidal potential: Insights into its structure and biological roles. Toxicon 2016, 120, 147-158. [CrossRef]

58. Macías-Rodríguez, E.F.; Díaz-Cárdenas, C.O.; Gatica-Colima, A.B.; Plenge-Tellechea, L.F. Seasonal variation in protein content and PLA2 activity of Crotalus molossus molossus venom from captive and wild specimens. Acta Univ. 2014, 24, 38-47. [CrossRef]

59. Rivas, E.; Neri, E.; Benard, M.I.; Hernánez-Dávila, A.; Zamudio, F.; Alagón, A. General characterization of the venoms from two species of rattlesnakes and an intergrade population (C. lepidus x aquilus) from Aguascalientes and Zacatecas, Mexico. Toxicon 2017, 138. [CrossRef] [PubMed]

60. Griffin, P.R.; Aird, S.D. A new small myotoxin from the venom of the prairie rattlesnake (Crotalus viridis viridis). FEBS Lett. 1990, 274, 43-47. [CrossRef] [PubMed]

61. Ownby, C.L.; Colberg, T.R.; White, S.P. Isolation, characterization and crystallization of a phospholipase A2 myotoxin from the venom of the prairie rattlesnake (Crotalus viridis viridis). Toxicon 1997, 35, 111-124. [CrossRef]

62. Saviola, A.J.; Pla, D.; Sanz, L.; Castoe, T.A.; Calvete, J.J.; Mackessy, S.P. Comparative venomics of the Prairie Rattlesnake (Crotalus viridis viridis) from Colorado: Identification of a novel pattern of ontogenetic changes in venom composition and assessment of the immunoreactivity of the commercial antivenom CroFab(R). J. Proteom. 2015, 121, 28-43. [CrossRef] [PubMed]

63. Strickland, J.L.; Mason, A.J.; Rokyta, D.R.; Parkinson, C.L. Phenotypic Variation in Mojave Rattlesnake (Crotalus scutulatus) Venom Is Driven by Four Toxin Families. Toxins 2018, 10, 135. [CrossRef]

64. Evangelista, J.S.A.M.; Martins, A.M.C.; Nascimento, N.R.F.; Sousa, C.M.; Alves, R.S.; Toyama, D.O.; Toyama, M.H.; Evangelista, J.J.F.; Menezes, D.B.d.; Fonteles, M.C.; et al. Renal and vascular effects of the natriuretic peptide isolated from Crotalus durissus cascavella venom. Toxicon Off. J. Int. Soc. Toxinol. 2008, 52, 737-744. [CrossRef]

65. Gomes, C.L.; Konno, K.; Conceição, I.M.; Ianzer, D.; Yamanouye, N.; Prezoto, B.C.; Assakura, M.T.; Rádis-Baptista, G.; Yamane, T.; Santos, R.A.; et al. Identification of novel bradykinin-potentiating peptides (BPPs) in the venom gland of a rattlesnake allowed the evaluation of the structure-function relationship of BPPs. Biochem. Pharmacol. 2007, 74, 1350-1360. [CrossRef]

66. Carey, C.M.; Bueno, R.; Gutierrez, D.A.; Petro, C.; Lucena, S.E.; Sanchez, E.E.; Soto, J.G. Recombinant rubistatin (r-Rub), an MVD disintegrin, inhibits cell migration and proliferation, and is a strong apoptotic inducer of the human melanoma cell line SK-Mel-28. Toxicon 2012, 59, 241-248. [CrossRef]

67. Saviola, A.J.; Modahl, C.M.; Mackessy, S.P. Disintegrins of Crotalus simus tzabcan venom: Isolation, characterization and evaluation of the cytotoxic and anti-adhesion activities of tzabcanin, a new RGD disintegrin. Biochimie 2015, 116, 92-102. [CrossRef]

68. Saviola, A.J.; Burns, P.D.; Mukherjee, A.K.; Mackessy, S.P. The disintegrin tzabcanin inhibits adhesion and migration in melanoma and lung cancer cells. Int. J. Biol. Macromol. 2016, 88, 457-464. [CrossRef] [PubMed] 
69. Roldán-Padrón, O.; Castro-Guillén, J.L.; García-Arredondo, J.A.; Cruz-Pérez, M.S.; Díaz-Peña, L.F.; Saldaña, C.; Blanco-Labra, A.; García-Gasca, T. Snake Venom Hemotoxic Enzymes: Biochemical Comparison between Crotalus Species from Central Mexico. Molecules 2019, 24, 1489. [CrossRef]

70. Gibbs, H.L.; Mackessy, S.P. Functional basis of a molecular adaptation: Prey-specific toxic effects of venom from Sistrurus rattlesnakes. Toxicon 2009, 53, 672-679. [CrossRef] [PubMed]

71. Gibbs, H.L.; Sanz, L.; Sovic, M.G.; Calvete, J.J. PMC3691181; Phylogeny-based comparative analysis of venom proteome variation in a clade of rattlesnakes (Sistrurus sp.). PLoS ONE 2013, 8, e67220. [CrossRef] [PubMed]

72. Casewell, N.R.; Wagstaff, S.C.; Wüster, W.; Cook, D.A.; Bolton, F.M.; King, S.I.; Pla, D.; Sanz, L.; Calvete, J.J.; Harrison, R.A. Medically important differences in snake venom composition are dictated by distinct postgenomic mechanisms. Proc. Natl. Acad. Sci. 2014, 111, 9205-9210. [CrossRef] [PubMed]

73. Xiong, S.; Huang, C. Synergistic Strategies of Predominant Toxins in Snake Venoms. Toxicol. Lett. 2018, 287. [CrossRef]

74. Groten, J.P.; Feron, V.J.; Sühnel, J. Toxicology of Simple and Complex Mixtures. Trends Pharmacol. Sci. 2001, 22. [CrossRef]

75. Buschek, S.; Ignjatovic, V.; Summerhayes, R.; Lowe, R. The effect of different snake venoms and anti-venoms on thrombin clotting time in human plasma. Thromb Res. 2010, 125, e149-e152. [CrossRef] [PubMed]

76. Castro, E.N.; Lomonte, B.; del Carmen Gutierrez, M.; Alagon, A.; Gutierrez, J.M. Intraspecies variation in the venom of the rattlesnake Crotalus simus from Mexico: Different expression of crotoxin results in highly variable toxicity in the venoms of three subspecies. J. Proteom. 2013, 87, 103-121. [CrossRef]

77. Viala, V.L.; Hildebrand, D.; Fucase, T.M.; Sciani, J.M.; Prezotto-Neto, J.P.; Riedner, M.; Sanches, L.; Nishimura, P.J.; Oguiura, N.; Pimenta, D.C.; et al. Proteomic analysis of the rare Uracoan rattlesnake Crotalus vegrandis venom: Evidence of a broad arsenal of toxins. Toxicon 2015, 107, 234-251. [CrossRef]

78. Margres, M.J.; McGivern, J.J.; Wray, K.P.; Seavy, M.; Calvin, K.; Rokyta, D.R. Linking the transcriptome and proteome to characterize the venom of the eastern diamondback rattlesnake (Crotalus adamanteus). J. Proteom. 2014, 96, 145-158. [CrossRef] [PubMed]

79. Rokyta, D.R.; Lemmon, A.R.; Margres, M.J.; Aronow, K. The venom-gland transcriptome of the eastern diamondback rattlesnake (Crotalus adamanteus). BMC Genom. 2012, 13, 312. [CrossRef]

80. Rokyta, D.R.; Wray, K.P.; Lemmon, A.R.; Lemmon, E.M.; Caudle, S.B. A high-throughput venom-gland transcriptome for the Eastern Diamondback Rattlesnake (Crotalus adamanteus) and evidence for pervasive positive selection across toxin classes. Toxicon Off. J. Int. Soc. Toxinol. 2011, 57, 657-671. [CrossRef]

81. Vincent, M.; Curti, B. On the Reaction Mechanism of Crotalus adamanteus 1-Amino Acid Oxidase. J. Biol. Chem. 1967, 242, 1259-1264.

82. Heinrikson, R.L.; Krueger, E.T.; Keim, P.S. Amino acid sequence of phospholipase A2-alpha from the venom of Crotalus adamanteus. A new classification of phospholipases A2 based upon structural determinants. J. Biol. Chem. 1977, 252, 4913-4921. [CrossRef]

83. Jia, Y.; Olvera, P.; Rangel, F.; Mendez, B.; Reddy, S. Rapid Identification of Phospholipase A2 Transcripts from Snake Venoms. Toxins 2019, 11, 69. [CrossRef]

84. Wellner, D.; Meister, A. Crystalline L-amino acid oxidase of Crotalus adamanteus. J. Biol. Chem. 1960, 235, 2013-2018. [CrossRef]

85. Samy, R.P.; Kandasamy, M.; Gopalakrishnakone, P.; Stiles, B.G.; Rowan, E.G.; Becker, D.; Shanmugam, M.K.; Sethi, G.; Chow, V.T.K. Wound healing activity and mechanisms of action of an antibacterial protein from the venom of the eastern diamondback rattlesnake (Crotalus adamanteus). PLoS ONE 2014, 9, e80199. [CrossRef]

86. Rokyta, D.R.; Margres, M.J.; Ward, M.J.; Sanchez, E.E. The genetics of venom ontogeny in the eastern diamondback rattlesnake (Crotalus adamanteus). PeerJ 2017, 5, e3249. [CrossRef] [PubMed]

87. Gomis-Rüth, F.X.; Kress, L.F.; Kellermann, J.; Mayr, I.; Lee, X.; Huber, R.; Bode, W. Refined $2 \cdot 0$ A X-ray Crystal Structure of the Snake Venom Zinc-endopeptidase Adamalysin II: Primary and Tertiary Structure Determination, Refinement, Molecular Structure and Comparison with Astacin, Collagenase and Thermolysin. J. Mol. Biol. 1994, 239, 513-544. [CrossRef]

88. Suntravat, M.; Langlais, P.R.; Sánchez, E.E.; Nielsen, V.G. CatroxMP-II: A heme-modulated fibrinogenolytic metalloproteinase isolated from Crotalus atrox venom. Biometals Int. J. Role Met. Ions Biol. Biochem. Med. 2018, 31, 585-593. [CrossRef] [PubMed]

89. Sultan, M.T.; Li, H.-M.; Lee, Y.Z.; Lim, S.S.; Song, D.-K. Identification of Lys49-PLA2 from crude venom of Crotalus atrox as a human neutrophil-calcium modulating protein. Korean J. Physiol. Pharmacol. 2016, 20, 177-183. [CrossRef]

90. Igarashi, T.; Araki, S.; Mori, H.; Takeda, S. Crystal structures of catrocollastatin/VAP2B reveal a dynamic, modular architecture of ADAM/adamalysin/reprolysin family proteins. FEBS Lett. 2007, 581, 2416-2422. [CrossRef] [PubMed]

91. Fox, J.W.; Serrano, S.M.T. Timeline of key events in snake venom metalloproteinase research. J. Proteom. 2009, 72, 200-209. [CrossRef]

92. Torii, S.; Naito, M.; Tsuruo, T. Apoxin I, a novel apoptosis-inducing factor with L-amino acid oxidase activity purified from Western diamondback rattlesnake venom. J. Biol. Chem. 1997, 272, 9539-9542. [CrossRef]

93. Kikushima, E.; Nakamura, S.; Oshima, Y.; Shibuya, T.; Miao, J.Y.; Hayashi, H.; Nikai, T.; Araki, S. Hemorrhagic activity of the vascular apoptosis-inducing proteins VAP1 and VAP2 from Crotalus atrox. Toxicon Off. J. Int. Soc. Toxinol. 2008, 52, 589-593. [CrossRef] [PubMed]

94. Bjarnason, J.B.; Fox, J.W. Proteolytic specificity and cobalt exchange of hemorrhagic toxin e, a zinc protease isolated from the venom of the western diamondback rattlesnake (Crotalus atrox). Biochemistry 1983, 22, 3770-3778. [CrossRef] 
95. Bjarnason, J.B.; Barish, A.; Direnzo, G.S.; Campbell, R.; Fox, J.W. Kallikrein-like Enzymes From Crotalus Atrox Venom. J. Biol. Chem. 1983, 258, 12566-12573. [CrossRef]

96. Segura, A.; Herrera, M.; Mares, F.R.; Jaime, C.; Sanchez, A.; Vargas, M.; Villalta, M.; Gomez, A.; Gutierrez, J.M.; Leon, G. Proteomic, toxicological and immunogenic characterization of Mexican west -coast rattlesnake (Crotalus basiliscus) venom and its immunological relatedness with the venom of Central American rattlesnake (Crotalus simus). J. Proteom. 2017, 158, 62-72. [CrossRef] [PubMed]

97. Datta, G.; Dong, A.; Witt, J.; Tu, A.T. Biochemical characterization of basilase, a fibrinolytic enzyme from Crotalus basiliscus basiliscus. Arch. Biochem. Biophys. 1995, 317, 365-373. [CrossRef]

98. Scarborough, R.M.; Rose, J.W.; Naughton, M.A.; Phillips, D.R.; Nannizzi, L.; Arfsten, A.; Campbell, A.M.; Charo, I.F. Characterization of the Integrin Specificities of Disintegrins Isolated From American Pit Viper Venoms. J. Biol. Chem. 1993, 268, $1058-1065$. [CrossRef]

99. Retzios, A.D.; Markland, J.F.S. Purification, characterization, and fibrinogen cleavage sites of three fibrinolytic enzymes from the venom of Crotalus basiliscus basiliscus. Biochemistry 1992, 31, 4547-4557. [CrossRef] [PubMed]

100. Rautsaw, R.M.; Hofmann, E.P.; Margres, M.J.; Holding, M.L.; Strickland, J.L.; Mason, A.J.; Rokyta, D.R.; Parkinson, C.L. Intraspecific sequence and gene expression variation contribute little to venom diversity in sidewinder rattlesnakes (Crotalus cerastes). Proc. Biol. Sci. 2019, 286. [CrossRef] [PubMed]

101. Hofmann, E.P.; Rautsaw, R.M.; Strickland, J.L.; Holding, M.L.; Hogan, M.P.; Mason, A.J.; Rokyta, D.R.; Parkinson, C.L. Comparative venom-gland transcriptomics and venom proteomics of four Sidewinder Rattlesnake (Crotalus cerastes) lineages reveal little differential expression despite individual variation. Sci. Rep. 2018, 8, 15534. [CrossRef] [PubMed]

102. Bosak, A.R.; Ruha, A.M.; Graeme, K.A. A case of neurotoxicity following envenomation by the Sidewinder rattlesnake, Crotalus cerastes. J. Med. Toxicol. 2014, 10, 229-231. [CrossRef]

103. Bandeira, I.C.J.; Bandeira-Lima, D.; Mello, C.P.; Pereira, T.P.; De Menezes, R.; Sampaio, T.L.; Falcao, C.B.; Radis-Baptista, G.; Martins, A.M.C. Antichagasic effect of crotalicidin, a cathelicidin-like vipericidin, found in Crotalus durissus terrificus rattlesnake's venom gland. Parasitology 2018, 145, 1059-1064. [CrossRef]

104. Wiezel, G.A.; Shibao, P.Y.T.; Cologna, C.T.; Morandi Filho, R.; Ueira-Vieira, C.; De Pauw, E.; Quinton, L.; Arantes, E.C. InDepth Venome of the Brazilian Rattlesnake Crotalus durissus terrificus: An Integrative Approach Combining Its Venom Gland Transcriptome and Venom Proteome. J. Proteome Res. 2018, 17, 3941-3958. [CrossRef] [PubMed]

105. Bordon, K.C.; Perino, M.G.; Giglio, J.R.; Arantes, E.C. Isolation, enzymatic characterization and antiedematogenic activity of the first reported rattlesnake hyaluronidase from Crotalus durissus terrificus venom. Biochimie 2012, 94, 2740-2748. [CrossRef]

106. de Oliveira, S.A.; Magalhaes, M.R.; de Oliveira, L.P.; da Cunha, L.C. Identification of antinociceptive fraction of snake venom from Crotalus durissus collilineatus crotamine-negative and its acute toxicity evaluation. Toxicon 2016, 122, 145-151. [CrossRef] [PubMed]

107. Lopes, D.M.; Junior, N.E.; Costa, P.P.; Martins, P.L.; Santos, C.F.; Carvalho, E.D.; Carvalho, M.D.; Pimenta, D.C.; Cardi, B.A.; Fonteles, M.C.; et al. A new structurally atypical bradykinin-potentiating peptide isolated from Crotalus durissus cascavella venom (South American rattlesnake). Toxicon 2014, 90, 36-44. [CrossRef] [PubMed]

108. Pereañez, J.A.; Núñez, V.; Huancahuire-Vega, S.; Marangoni, S.; Ponce-Soto, L.A. Biochemical and Biological Characterization of a PLA2 From Crotoxin Complex of Crotalus Durissus Cumanensis. Toxicon Off. J. Int. Soc. Toxinol. 2009, 53. [CrossRef]

109. Marcussi, S.; Santos, P.R.S.; Menaldo, D.L.; Silveira, L.B.; Santos-Filho, N.; Mazzi, M.V.; da Silva, S.L.; Stábeli, R.G.; Antunes, L.M.G.; Soares, A.M. Evaluation of the genotoxicity of Crotalus durissus terrificus snake venom and its isolated toxins on human lymphocytes. Mutat. Res. 2011, 724, 59-63. [CrossRef] [PubMed]

110. Shimizu, J.F.; Pereira, C.M.; Bittar, C.; Batista, M.N.; Campos, G.R.F.; da Silva, S.; Cintra, A.C.O.; Zothner, C.; Harris, M.; Sampaio, S.V.; et al. Multiple effects of toxins isolated from Crotalus durissus terrificus on the hepatitis $\mathrm{C}$ virus life cycle. PLoS ONE 2017, 12, e0187857. [CrossRef]

111. Cavalcante, W.L.; Ponce-Soto, L.A.; Marangoni, S.; Gallacci, M. Neuromuscular effects of venoms and crotoxin-like proteins from Crotalus durissus ruruima and Crotalus durissus cumanensis. Toxicon 2015, 96, 46-49. [CrossRef]

112. Cavalcante, W.L.G.; Noronha-Matos, J.B.; Timoteo, M.A.; Fontes, M.R.M.; Gallacci, M.; Correia-de-Sa, P. Neuromuscular paralysis by the basic phospholipase A2 subunit of crotoxin from Crotalus durissus terrificus snake venom needs its acid chaperone to concurrently inhibit acetylcholine release and produce muscle blockage. Toxicol Appl. Pharmacol. 2017, 334, 8-17. [CrossRef]

113. Costa, C.R.C.; Belchor, M.N.; Rodrigues, C.F.B.; Toyama, D.O.; de Oliveira, M.A.; Novaes, D.P.; Toyama, M.H. Edema Induced by a Crotalus durissus terrificus Venom Serine Protease (Cdtsp 2) Involves the PAR Pathway and PKC and PLC Activation. Int. J. Mol. Sci. 2018, 19, 2405. [CrossRef] [PubMed]

114. de Oliveira, S.A.M.; Magalhães, M.R.; Salazar, V.C.R.; Valadares, M.C.; da Cunha, L.C. Identification of crotamine in the venom of Crotalus durissus collilineatus by three different methods. Toxicon 2015, 95, 46-51. [CrossRef]

115. de Oliveira, L.A.; Ferreira, R.S., Jr.; Barraviera, B.; de Carvalho, F.C.T.; de Barros, L.C.; Dos Santos, L.D.; Pimenta, D.C. Crotalus durissus terrificus crotapotin naturally displays preferred positions for amino acid substitutions. J. Venom. Anim. Toxins Incl. Trop. Dis. 2017, 23, 46. [CrossRef] [PubMed]

116. Freitas, A.P.; Favoretto, B.C.; Clissa, P.B.; Sampaio, S.C.; Faquim-Mauro, E.L. Crotoxin Isolated from Crotalus durissus terrificus Venom Modulates the Functional Activity of Dendritic Cells via Formyl Peptide Receptors. J. Immunol. Res. 2018, 2018, 7873257. [CrossRef] 
117. Muller, V.D.; Soares, R.O.; dos Santos, N.N., Jr.; Trabuco, A.C.; Cintra, A.C.; Figueiredo, L.T.; Caliri, A.; Sampaio, S.V.; Aquino, V.H. Phospholipase A2 isolated from the venom of Crotalus durissus terrificus inactivates dengue virus and other enveloped viruses by disrupting the viral envelope. PLoS ONE 2014, 9, e112351. [CrossRef]

118. Vargas, L.J.; Quintana, J.C.; Pereanez, J.A.; Nunez, V.; Sanz, L.; Calvete, J. Cloning and characterization of an antibacterial L-amino acid oxidase from Crotalus durissus cumanensis venom. Toxicon 2013, 64, 1-11. [CrossRef]

119. Rokyta, D.R.; Wray, K.P.; Margres, M.J. The genesis of an exceptionally lethal venom in the timber rattlesnake (Crotalus horridus) revealed through comparative venom-gland transcriptomics. BMC Genom. 2013, 14, 394. [CrossRef]

120. Galán, J.A.; Sánchez, E.E.; Bashir, S.A.; Pérez, J.C. Characterization and identification of disintegrins in Crotalus horridus venom by liquid chromatography and tandem matrix-assisted laser desorption ionization-Quadrupole ion trap time-of-flight (MALDIQIT-TOF) mass spectrometry. Can. J. Chem. 2005, 83, 1124-1131. [CrossRef]

121. Borja, M.; Galan, J.A.; Cantu, E., Jr.; Zugasti-Cruz, A.; Rodriguez-Acosta, A.; Lazcano, D.; Lucena, S.; Suntravat, M.; Sanchez, Y.E.E. Morulustatin, A Disintegrin that Inhibits ADP-Induced Platelet Aggregation, Isolated from the Mexican Tamaulipan Rock Rattlesnake (Crotalus lepidus morulus). Rev. Cient. 2016, 26, 86-94.

122. Martinez-Romero, G.; Rucavado, A.; Lazcano, D.; Gutierrez, J.M.; Borja, M.; Lomonte, B.; Garza-Garcia, Y.; Zugasti-Cruz, A. Comparison of venom composition and biological activities of the subspecies Crotalus lepidus lepidus, Crotalus lepidus klauberi and Crotalus lepidus morulus from Mexico. Toxicon 2013, 71, 84-95. [CrossRef]

123. Borja, M.; Lazcano, D.; Martínez-Romero, G.; Morlett, J.; Sánchez, E.; Cepeda-Nieto, A.C.; Garza-García, Y.; Zugasti-Cruz, A. Intra-specific Variation in the Protein Composition and Proteolytic Activity of Venom of Crotalus lepidus morulus from the Northeast of Mexico. Copeia 2013, 2013, 707-716. [CrossRef]

124. Holzer, M.; Mackessy, S.P. An aqueous endpoint assay of snake venom phospholipase A2. Toxicon 1996, 34, 1149-1155. [CrossRef]

125. Tan, K.K.; Ler, S.G.; Gunaratne, J.; Bay, B.H.; Ponnampalam, G. In Vitro Cytotoxicity of L-amino Acid Oxidase From the Venom of Crotalus Mitchellii Pyrrhus. Toxicon Off. J. Int. Soc. Toxinol. 2017, 139. [CrossRef]

126. Melendez-Martinez, D.; Macias-Rodriguez, E.; Vazquez-Briones, R.; Lopez-Vera, E.; Sandra Cruz-Perez, M.; Vargas-Caraveo, A.; Gatica-Colima, A.; Fernando Plenge-Tellechea, L. In vitro hemotoxic, alpha-neurotoxic and vasculotoxic effects of the Mexican black-tailed rattlesnake (Crotalus molossus nigrescens) venom. J. Venom Res. 2017, 8, 1-8.

127. Rael, E.D.; Martinez, M.; Molina, O. Isolation of a fibrinolytic protease, M4, from venom of Crotalus molossus molossus (northern blacktail rattlesnake). Haemostasis 1992, 22, 41-49. [CrossRef] [PubMed]

128. Borja, M.; Neri-Castro, E.; Perez-Morales, R.; Strickland, J.L.; Ponce-Lopez, R.; Parkinson, C.L.; Espinosa-Fematt, J.; Saenz-Mata, J.; Flores-Martinez, E.; Alagon, A.; et al. Ontogenetic Change in the Venom of Mexican Black-Tailed Rattlesnakes (Crotalus molossus nigrescens). Toxins 2018, 10, 501. [CrossRef]

129. Chen, T.; Rael, E.D. Purification of M5, a fibrinolytic proteinase from Crotalus molossus molossus venom that attacks complement. Int. J. Biochem. Cell Biol. 1997, 29, 789-799. [CrossRef]

130. Sanchez, E.E.; Soliz, L.A.; Ramirez, M.S.; Perez, J.C. Partial characterization of a basic protein from Crotalus molossus molossus (northern blacktail rattlesnake) venom and production of a monoclonal antibody. Toxicon 2001, 39, 523-537. [CrossRef]

131. Sanchez, E.E.; Gonzalez, R.; Lucena, S.; Garcia, S.; Finol, H.J.; Suntravat, M.; Giron, M.E.; Fernandez, I.; Rodriguez-Acosta, A. Crotamine-like from Southern Pacific rattlesnake (Crotalus oreganus helleri) Venom acts on human leukemia (K-562) cell lines and produces ultrastructural changes on mice adrenal gland. Ultrastruct. Pathol. 2018, 42, 116-123. [CrossRef] [PubMed]

132. Martins, W.; Baldasso, P.A.; Honorio, K.M.; Maltarollo, V.G.; Ribeiro, R.I.; Carvalho, B.M.; Soares, A.M.; Calderon, L.A.; Stabeli, R.G.; Caballol, M.A.; et al. A novel phospholipase A2 (D49) from the venom of the Crotalus oreganus abyssus (North American Grand canyon rattlesnake). BioMed Res. Int. 2014, 2014, 654170. [CrossRef]

133. Da Silva, S.L.; Dias-Junior, C.A.; Baldasso, P.A.; Damico, D.C.S.; Carvalho, B.M.A.; Garanto, A.; Acosta, G.; Oliveira, E.; Albericio, F.; Soares, A.M.; et al. Vascular effects and electrolyte homeostasis of the natriuretic peptide isolated from Crotalus oreganus abyssus (North American Grand Canyon rattlesnake) venom. Peptides 2012, 36, 206-212. [CrossRef]

134. Salazar, A.M.; Guerrero, B.; Cantu, B.; Cantu, E.; Rodríguez-Acosta, A.; Pérez, J.C.; Galán, J.A.; Tao, A.; Sánchez, E.E. Venom Variation in Hemostasis of the Southern Pacific Rattlesnake (Crotalus Oreganus Helleri): Isolation of Hellerase. Comp. Biochem. Physiol. Toxicol. Pharmacol. CBP 2009, 149. [CrossRef] [PubMed]

135. Sunagar, K.; Undheim, E.A.; Scheib, H.; Gren, E.C.; Cochran, C.; Person, C.E.; Koludarov, I.; Kelln, W.; Hayes, W.K.; King, G.F.; et al. Intraspecific Venom Variation in the Medically Significant Southern Pacific Rattlesnake (Crotalus Oreganus Helleri): Biodiscovery, Clinical and Evolutionary Implications. J. Proteom. 2014, 99. [CrossRef]

136. Almeida, J.R.; Mendes, B.; Lancellotti, M.; Marangoni, S.; Vale, N.; Passos, O.; Ramos, M.J.; Fernandes, P.A.; Gomes, P.; Da Silva, S.L. A novel synthetic peptide inspired on Lys49 phospholipase A2 from Crotalus oreganus abyssus snake venom active against multidrug-resistant clinical isolates. Eur. J. Med. Chem. 2018, 149, 248-256. [CrossRef] [PubMed]

137. Marquez, J.; Parra, V.; Suntravat, M.; Sanchez, E.E. Purification and characterization of cysteine rich-secretory proteins (CRiSPs) from the venom of the Southern Pacific rattlesnake (Crotalus oreganus helleri): Their role on blood and lymphatic endothelial cell permeability. Toxicon 2018, 150, 315-334. [CrossRef]

138. Hamako, J.; Suzuki, Y.; Hayashi, N.; Kimura, M.; Ozeki, Y.; Hashimoto, K.; Matsui, T. Amino acid sequence and characterization of C-type lectin purified from the snake venom of Crotalus ruber. Comp. Biochem. Physiol. B Biochem. Mol. Biol. 2007, 146, 299-306. [CrossRef] 
139. Mori, N.; Sugihara, H. Comparative study of two arginine ester hydrolases, E-I and E-II from the venom of Crotalus ruber ruber (red rattlesnake). Comp. Biochem. Physiol. B 1989, 92, 537-547. [CrossRef]

140. Straight, R.C.; Glenn, J.L.; Wolt, T.B.; Wolfe, M.C. North-south regional variation in phospholipase A activity in the venom of Crotalus ruber. Comp. Biochem. Physiol. B 1992, 103, 635-639. [CrossRef]

141. Mori, N.; Nikai, T.; Sugihara, H.; Tu, A.T. Biochemical characterization of hemorrhagic toxins with fibrinogenase activity isolated from Crotalus ruber ruber venom. Arch. Biochem. Biophys 1987, 253, 108-121. [CrossRef]

142. Mori, N.; Nikai, T.; Sugihara, H. Phosphodiesterase from the venom of Crotalus ruber ruber. Int. J. Biochem. 1987, 19, 115-119. [CrossRef]

143. Mori, N.; Sugihara, H. Characterization of kallikrein-like enzyme from Crotalus ruber ruber (red rattlesnake) venom. Int. J. Biochem. 1989, 21, 83-90. [CrossRef]

144. Sanchez, E.E.; Galan, J.A.; Powell, R.L.; Reyes, S.R.; Soto, J.G.; Russell, W.K.; Russell, D.H.; Perez, J.C. Disintegrin, hemorrhagic, and proteolytic activities of Mohave rattlesnake, Crotalus scutulatus scutulatus venoms lacking Mojave toxin. Comp. Biochem. Physiol. C Toxicol. Pharmacol. 2005, 141, 124-132. [CrossRef]

145. Borja, M.; Castañeda, G.; Espinosa, J.; Neri, E.; Carbajal, A.; Clement, H.; García, O.; Alagon, A. Mojave Rattlesnake (Crotalus scutulatus scutulatus) with Type B Venom from Mexico. Copeia 2014, 2014, 7-13. [CrossRef]

146. Massey, D.J.; Calvete, J.J.; Sanchez, E.E.; Sanz, L.; Richards, K.; Curtis, R.; Boesen, K. Venom variability and envenoming severity outcomes of the Crotalus scutulatus scutulatus (Mojave rattlesnake) from Southern Arizona. J. Proteom. 2012, 75, 2576-2587. [CrossRef] [PubMed]

147. Hinson, M.W.; Childs, C.; Johnson, B.D.; Sifford, D.H. Concanavalin A-Binding Enzymes of Crotalus scutulatus scutulatus Venom. J. Ark. Acad. Sci. 1985, 39, 50-54.

148. Ho, C.L.; Lee, C.Y. Presynaptic actions of Mojave toxin isolated from Mojave rattlesnake (crotalus scutulatus) venom. Toxicon 1981, 19, 889-892. [CrossRef]

149. Modahl, C.M.; Mackessy, S.P. Full-Length Venom Protein cDNA Sequences from Venom-Derived mRNA: Exploring Compositional Variation and Adaptive Multigene Evolution. PLoS Negl. Trop. Dis. 2016, 10, e0004587. [CrossRef]

150. Durban, J.; Sanz, L.; Trevisan-Silva, D.; Neri-Castro, E.; Alagon, A.; Calvete, J.J. Integrated Venomics and Venom Gland Transcriptome Analysis of Juvenile and Adult Mexican Rattlesnakes Crotalus simus, C. tzabcan, and C. culminatus Revealed miRNA-modulated Ontogenetic Shifts. J. Proteome Res. 2017, 16, 3370-3390. [CrossRef]

151. Nielsen, V.G.; Boyer, L.V.; Redford, D.T.; Ford, P. Thrombelastographic characterization of the thrombin-like activity of Crotalus simus and Bothrops asper venoms. Blood Coagul. Fibrinolysis 2017, 28, 211-217. [CrossRef]

152. Weinstein, S.A.; Smith, L.A. Preliminary fractionation of tiger rattlesnake (Crotalus tigris) venom. Toxicon 1990, $28,1447-1455$. [CrossRef]

153. Minton, S.A.; Weinstein, S.A. Protease activity and lethal toxicity of venoms from some little known rattlesnakes. Toxicon 1984, 22, 828-830. [CrossRef]

154. Powell, R.L.; Lieb, C.S.; Rael, E.D. Identification of a neurotoxic venom component in the Tiger rattlesnake, Crotalus tigris. J. Herpetol. 2004, 38, 149-152. [CrossRef]

155. Kaiser, I.I.; Aird, S.D. A crotoxin homolog from the venom of the Uracoan rattlesnake (Crotalus vegrandis). Toxicon 1987, 25, 1113-1120. [CrossRef]

156. Scannone, H.R.; Rodriguez, O.G.; Lancini, A.R. Enzymatic activities and other characteristics of Crotalus vegrandis snake venom. In Toxins: Animals, Plants and Microbials; Rosenberg, P., Ed.; Pergamon Press: New York, NY, USA, 1978; pp. 223-229. [CrossRef]

157. Moore, S.W.; Bhat, V.K.; Flatt, P.R.; Gault, V.A.; McClean, S. Isolation and characterisation of insulin-releasing compounds from Crotalus adamanteus, Crotalus vegrandis and Bitis nasicornis venom. Toxicon 2015, 101, 48-54. [CrossRef]

158. Giron, M.; Pinto, A.; Finol, H.J.; Aguilar, I.; Rodriguez-Acosta, A. Kidney structural and ultrastructural pathological changes induced by uracoan rattlesnake (Crotalus vegrandis Klauber 1941) venom. J. Submicrosc. Cytol. Pathol. 2002, 34, 447-459. [PubMed]

159. Aguilar, I.; Giron, M.E.; Rodriguez-Acosta, A. Purification and characterisation of a haemorrhagic fraction from the venom of the Uracoan rattlesnake Crotalus vegrandis. Biochim. Biophys. Acta 2001, 1548, 57-65. [CrossRef]

160. Adade, C.; Fernandes Anne Cristine, S.; Carvalho Ana Lúcia, O.; Zingali, R.; Souto-Padrón, T. 44. Leishmanicidal Effects of a Phospholipase A2 Isolated from Crotalus viridis viridis Snake Venom. Toxicon 2012, 60, 117. [CrossRef]

161. Adade, C.M.; Cons, B.L.; Melo, P.A.; Souto-Padron, T. Effect of Crotalus viridis viridis snake venom on the ultrastructure and intracellular survival of Trypanosoma cruzi. Parasitology 2011, 138, 46-58. [CrossRef]

162. Zancolli, G.; Baker, T.G.; Barlow, A.; Bradley, R.K.; Calvete, J.J.; Carter, K.C.; de Jager, K.; Owens, J.B.; Price, J.F.; Sanz, L.; et al. Is Hybridization a Source of Adaptive Venom Variation in Rattlesnakes? A Test, Using a Crotalus scutulatus $\times$ viridis Hybrid Zone in Southwestern New Mexico. Toxins 2016, 8, 188. [CrossRef]

163. Nget-Hong, T.; Ponnudurai, G. A Comparative Study of the Biological Activities of Rattlesnake (Genera Crotalus and Sistrurus) Venoms. Comp. Biochem. Physiol. C Comp. Pharmacol. Toxicol. 1991, 98. [CrossRef]

164. Borgelt, C. Frequent item set mining. Wiley Interdiscip. Rev. Data Min. Knowl. Discov. 2012, 2, 437-456. [CrossRef]

165. Agrawal, R.; Imieliński, T.; Swami, A. Mining association rules between sets of items in large databases. In Proceedings of the 1993 ACM SIGMOD international conference on Management of data, Washington, DC, USA, 26-28 May 1993; pp. 207-216. 
166. Hahsler, M.; Chelluboina, S. Visualizing association rules: Introduction to the R-extension package arulesViz. R Proj. Modul. 2011, 223-238.

167. Hornik, K.; Grün, B.; Hahsler, M. arules-A computational environment for mining association rules and frequent item sets. J. Stat. Softw. 2005, 14, 1-25.

168. Pahari, S.; Mackessy, S.P.; Kini, R.M. The venom gland transcriptome of the Desert Massasauga rattlesnake (Sistrurus catenatus edwardsii): Towards an understanding of venom composition among advanced snakes (Superfamily Colubroidea). BMC Mol. Biol. 2007, 8, 115. [CrossRef] [PubMed]

169. Doley, R.; Pahari, S.; Mackessy, S.P.; Kini, R.M. Accelerated exchange of exon segments in Viperid three-finger toxin genes (Sistrurus catenatus edwardsii; Desert Massasauga). BMC Evol. Biol. 2008, 8, 196. [CrossRef]

170. Lisle Gibbs, H.; Chiucchi, J.E. Deconstructing a complex molecular phenotype: Population-level variation in individual venom proteins in Eastern Massasauga Rattlesnakes (Sistrurus c. catenatus). J. Mol. Evol. 2011, 72, 383-397. [CrossRef]

171. Sunagar, K.; Jackson, T.N.; Undheim, E.A.; Ali, S.A.; Antunes, A.; Fry, B.G. Three-fingered RAVERs: Rapid Accumulation of Variations in Exposed Residues of snake venom toxins. Toxins 2013, 5, 2172-2208. [CrossRef]

172. Chapeaurouge, A.; Reza, M.A.; Mackessy, S.P.; Carvalho, P.C.; Valente, R.H.; Teixeira-Ferreira, A.; Perales, J.; Lin, Q.; Kini, R.M. Interrogating the Venom of the Viperid Snake Sistrurus catenatus edwardsii by a Combined Approach of Electrospray and MALDI Mass Spectrometry. PLoS ONE 2015, 10, e0092091. [CrossRef]

173. Gibbs, H.L.; Sanz, L.; Calvete, J.J. Snake population venomics: Proteomics-based analyses of individual variation reveals significant gene regulation effects on venom protein expression in Sistrurus rattlesnakes. J. Mol. Evol. 2009, 68, 113-125. [CrossRef]

174. Juarez, P.; Sanz, L.; Calvete, J.J. Snake venomics: Characterization of protein families in Sistrurus barbouri venom by cysteine mapping, N-terminal sequencing, and tandem mass spectrometry analysis. Proteomics 2004, 4, 327-338. [CrossRef]

175. Gibbs, H.L.; Sanz, L.; Chiucchi, J.E.; Farrell, T.M.; Calvete, J.J. Proteomic analysis of ontogenetic and diet-related changes in venom composition of juvenile and adult Dusky Pigmy rattlesnakes (Sistrurus miliarius barbouri). J. Proteom. 2011, 74, 2169-2179. [CrossRef] [PubMed]

176. Sanz, L.; Gibbs, H.L.; Mackessy, S.P.; Calvete, J.J. Venom Proteomes of Closely Related Sistrurus Rattlesnakes with Divergent Diets. J. Proteome Res. 2006, 5, 2098-2112. [CrossRef]

177. Carstairs, S.D.; Kreshak, A.A.; Tanen, D.A. Crotaline Fab antivenom reverses platelet dysfunction induced by Crotalus scutulatus venom: An in vitro study. Acad. Emerg. Med. 2013, 20, 522-525. [CrossRef]

178. Strydom, D.J.; Botes, D.P. Snake Venom Toxins. I. Preliminary Studies on the Separation of Toxins of Elapidae Venoms. Toxicon Off. J. Int. Soc. Toxinol. 1970, 8. [CrossRef]

179. Laustsen, A.H. Toxin synergism in snake venoms. Toxin Rev. 2016, 35, 165-170. [CrossRef]

180. Lomeo, R.D.S.; Gonçalves, A.P.D.F.; Silva, C.N.D.; de Paula, A.T.; Costa Santos, D.O.; Fortes-Dias, C.; Gomes, D.A.; de Lima, M.E. Crotoxin from Crotalus durissus terrificus snake venom induces the release of glutamate from cerebrocortical synaptosomes via $\mathrm{N}$ and $\mathrm{P} / \mathrm{Q}$ calcium channels. Toxicon 2014, 85, 5-16. [CrossRef]

181. Faure, G.; Xu, H.; Saul, F.A. Crystal structure of crotoxin reveals key residues involved in the stability and toxicity of this potent heterodimeric $\beta$-neurotoxin. J. Mol. Biol. 2011, 412, 176-191. [CrossRef]

182. Gay, C.C.; Leiva, L.C.; Maruñak, S.; Teibler, P.; De Pérez, O.A. Proteolytic, Edematogenic and Myotoxic Activities of a Hemorrhagic Metalloproteinase Isolated From Bothrops Alternatus Venom. Toxicon Off. J. Int. Soc. Toxinol. 2005, 46. [CrossRef]

183. Denegri, M.E.G.; Acosta, O.C.; Huancahuire-Vega, S.; Martins-de-Souza, D.; Marangoni, S.; Maruñak, S.L.; Teibler, G.P.; Leiva, L.C.; Ponce-Soto, L.A. Isolation and Functional Characterization of a New Acidic PLA(2) Ba SpII RP4 of the Bothrops Alternatus Snake Venom From Argentina. Toxicon Off. J. Int. Soc. Toxinol. 2010, 56. [CrossRef]

184. Bustillo, S.; Gay, C.C.; Denegri, M.E.G.; Ponce-Soto, L.A.; de Kier Joffé, E.B.; Acosta, O.; Leiva, L.C. Synergism Between Baltergin Metalloproteinase and Ba SPII RP4 PLA2 from Bothrops Alternatus Venom on Skeletal Muscle (C2C12) Cells. Toxicon Off. J. Int. Soc. Toxinol. 2012, 59. [CrossRef]

185. Bustillo, S.; García-Denegri, M.E.; Gay, C.; Van de Velde, A.C.; Acosta, O.; Angulo, Y.; Lomonte, B.; Gutiérrez, J.M.; Leiva, L. Phospholipase A(2) Enhances the Endothelial Cell Detachment Effect of a Snake Venom Metalloproteinase in the Absence of Catalysis. Chem. Biol. Interact. 2015, 240. [CrossRef]

186. Šribar, J.; Oberčkal, J.; Križaj, I. Understanding the Molecular Mechanism Underlying the Presynaptic Toxicity of Secreted Phospholipases A(2): An Update. Toxicon Off. J. Int. Soc. Toxinol. 2014, 89. [CrossRef]

187. Higuchi, S.; Murayama, N.; Saguchi, K.; Ohi, H.; Fujita, Y.; Camargo, A.C.; Ogawa, T.; Deshimaru, M.; Ohno, M. Bradykininpotentiating peptides and C-type natriuretic peptides from snake venom. Immunopharmacology 1999, 44, 129-135. [CrossRef]

188. Murayama, N.; Hayashi, M.A.; Ohi, H.; Ferreira, L.A.; Hermann, V.V.; Saito, H.; Fujita, Y.; Higuchi, S.; Fernandes, B.L.; Yamane, T.; et al. Cloning and sequence analysis of a Bothrops jararaca cDNA encoding a precursor of seven bradykinin-potentiating peptides and a C-type natriuretic peptide. Proc. Natl. Acad. Sci. USA 1997, 94, 1189-1193. [CrossRef]

189. Rebello Horta, C.C.; Chatzaki, M.; Rezende, B.A.; Magalhaes Bde, F.; Duarte, C.G.; Felicori, L.F.; Ribeiro Oliveira-Mendes, B.B.; do Carmo, A.O.; Chavez-Olortegui, C.; Kalapothakis, E. Cardiovascular-Active Venom Toxins: An Overview. Curr. Med. Chem. 2016, 23, 603-622. [CrossRef]

190. Cushman, D.W.; Ondetti, M.A. History of the design of captopril and related inhibitors of angiotensin converting enzyme. Hypertension 1991, 17, 589-592. [CrossRef] [PubMed] 
191. Zhang, Y.; Xu, W.; Ma, B.; Huang, K.; Song, M.; Zhang, N.; Zhang, Y.; Wang, Y.; Dai, Y.; Luo, Y. Isolation and Characterisation of a Kallikrein-Like Enzyme from Agkistrodon Halys Pallas Snake Venom. J. Sci. Food Agric. 2012, 92. [CrossRef] [PubMed]

192. Hayashi, M.A.; Camargo, A.C. The Bradykinin-potentiating Peptides from Venom Gland and Brain of Bothrops Jararaca Contain Highly Site Specific Inhibitors of the Somatic Angiotensin-Converting Enzyme. Toxicon Off. J. Int. Soc. Toxinol. 2005, 45. [CrossRef]

193. Budnitskaya, P.; Gapanhuk, E.; Henriques, O.B. Comparative Action of Various Kininogenases on Crude Horse Plasma Substrates. Biochem. Pharmacol. 1970, 19. [CrossRef]

194. Felicori, L.F.; Souza, C.T.; Velarde, D.T.; Magalhaes, A.; Almeida, A.P.; Figueiredo, S.; Richardson, M.; Diniz, C.R.; Sanchez, E.F. Kallikrein-like Proteinase from Bushmaster Snake Venom. Protein Expr. Purif. 2003, 30. [CrossRef]

195. Soto, J.G.; White, S.A.; Reyes, S.R.; Regalado, R.; Sanchez, E.E.; Perez, J.C. Molecular evolution of PIII-SVMP and RGD disintegrin genes from the genus Crotalus. Gene 2007, 389, 66-72. [CrossRef]

196. Calvete, J.J.; Moreno-Murciano, M.P.; Theakston, R.D.; Kisiel, D.G.; Marcinkiewicz, C. Snake venom disintegrins: Novel dimeric disintegrins and structural diversification by disulphide bond engineering. Biochem. J. 2003, 372, 725-734. [CrossRef]

197. Markland, F.S.; Swenson, S. Snake venom metalloproteinases. Toxicon 2013, 62, 3-18. [CrossRef] [PubMed]

198. Baramova, E.N.; Shannon, J.D.; Bjarnason, J.B.; Gonias, S.L.; Fox, J.W. Interaction of Hemorrhagic Metalloproteinases With Human Alpha 2-macroglobulin. Biochemistry 1990, 29. [CrossRef]

199. Calvete, J.J.; Marcinkiewicz, C.; Monleon, D.; Esteve, V.; Celda, B.; Juarez, P.; Sanz, L. Snake venom disintegrins: Evolution of structure and function. Toxicon 2005, 45, 1063-1074. [CrossRef]

200. Yee, K.T.; Pitts, M.; Tongyoo, P.; Rojnuckarin, P.; Wilkinson, M.C. Snake Venom Metalloproteinases and Their Peptide Inhibitors from Myanmar Russell's Viper Venom. Toxins 2017, 9, 15. [CrossRef]

201. Sunagar, K.; Fry, B.G.; Jackson, T.N.W.; Casewell, N.R.; Undheim, E.A.B.; Vidal, N.; Ali, S.A.; King, G.F.; Vasudevan, K.; Vasconcelos, V.; et al. Molecular Evolution of Vertebrate Neurotrophins: Co-Option of the Highly Conserved Nerve Growth Factor Gene into the Advanced Snake Venom Arsenalf. PLoS ONE 2013, 8, e81827. [CrossRef]

202. Wijeyewickrema, L.C.; Gardiner, E.E.; Gladigau, E.L.; Berndt, M.C.; Andrews, R.K. Nerve growth factor inhibits metalloproteinasedisintegrins and blocks ectodomain shedding of platelet glycoprotein VI. J. Biol. Chem. 2010, 285, 11793-11799. [CrossRef]

203. Frade, J.M.; Barde, Y.A. Genetic Evidence for Cell Death Mediated by Nerve Growth Factor and the Neurotrophin Receptor p75 in the Developing Mouse Retina and Spinal Cord. Development 1999, 126, 683-690. [CrossRef] [PubMed]

204. Frade, J.M.; Rodríguez-Tébar, A.; Barde, Y.A. Induction of Cell Death by Endogenous Nerve Growth Factor Through Its p75 Receptor. Nature 1996, 383. [CrossRef]

205. Girish, K.S.; Jagadeesha, D.K.; Rajeev, K.B.; Kemparaju, K. Snake Venom Hyaluronidase: An Evidence for Isoforms and Extracellular Matrix Degradation. Mol. Cell. Biochem. 2002, 240. [CrossRef] [PubMed]

206. Payne, V.; Kam, P.C.A. Mast Cell Tryptase: A Review of Its Physiology and Clinical Significance. Anaesthesia 2004, 59. [CrossRef] [PubMed]

207. Reyes-Velasco, J.; Meik, J.M.; Smith, E.N.; Castoe, T.A. Phylogenetic relationships of the enigmatic longtailed rattlesnakes (Crotalus ericsmithi, C. lannomi, and C. stejnegeri). Mol. Phylogenet Evol. 2013, 69, 524-534. [CrossRef] [PubMed]

208. Nunes Edos, S.; de Souza, M.A.; Vaz, A.F.; Santana, G.M.; Gomes, F.S.; Coelho, L.C.; Paiva, P.M.; da Silva, R.M.; Silva-Lucca, R.A.; Oliva, M.L.; et al. Purification of a lectin with antibacterial activity from Bothrops leucurus snake venom. Comp. Biochem. Physiol. B Biochem. Mol. Biol. 2011, 159, 57-63. [CrossRef]

209. Niewiarowski, S.; McLane, M.A.; Kloczewiak, M.; Stewart, G.J. Disintegrins and Other Naturally Occurring Antagonists of Platelet Fibrinogen Receptors. Semin. Hematol. 1994, 31, 289-300.

210. Pinheiro, E.; Bogen, D.L.; Hoxha, D.; Ciolino, J.D.; Wisner, K.L. Sertraline and breastfeeding: Review and meta-analysis. Arch. Women's Ment. Health 2015, 18. [CrossRef] 